\title{
Dekoracja stropu w kamienicy Jacoba Heinricha Zerneckego przy ul. Żeglarskiej 16 oraz dzieje toruńskiej rodziny malarskiej Tiedemanów
}

\author{
Barttomiej Łyczak \\ Krzysztof Mikulski**
}

W licznych kamienicach na toruńskiej starówce odnaleźć można stropy ozdobione w epoce nowożytnej dekoracjami malarskimi. Wykonywane były one przez miejscowych twórców, od $1621 \mathrm{r}$. zrzeszonych w cechu malarskim. Zagadnieniu temu poświęcona była książka Krystyny Kalinowskiej wydana w 1995 r. ${ }^{1}$ Od tego czasu udało się odkryć nowe, nieznane wcześniej dzieła. Należy do nich kompozycja zdobiąca strop sieni w kamienicy przy ul. Żeglarskiej 16, odkryta w 2016 r. w związku z pracami remontowo-adaptacyjnymi ${ }^{2}$. Malowidło powstało na początku XVIII w., gdy budynek ten należał do Jacoba Heinricha Zerneckego (1672-1741), toruńskiego kronikarza, historyka i burmistrza ${ }^{3}$.

${ }^{*}$ Dr, historyk sztuki, stopień doktora nauk humanistycznych w zakresie historii uzyskał na podstawie rozprawy „Toruński cech rzeźbiarski i snycerka na obszarze jego oddziaływania w latach 1695-1793" opublikowanej w 2018 r.

** Prof. dr hab., kierownik Zakładu Historii Gospodarczej oraz Centrum Badań Kopernikańskich na Wydziale Nauk Historycznych UMK, profesor w Instytucie Historii PAN, prezes Polskiego Towarzystwa Historycznego oraz Towarzystwa Miłośników Torunia.

${ }^{1}$ K. Kalinowska, Malowane stropy w kamienicach Torunia XVI-XVIII w., Warszawa 1995 .

${ }^{2}$ H. Belczyk, K. Rajman, Dokumentacja prac konserwatorskich przy stropie polichromowanym traktu przedniego parteru kamienicy przy ul. Żeglarskiej $16 \mathrm{w}$ Toruniu, Bydgoszcz 2016-2017, mps w Archiwum Miejskiego Konserwatora Zabytków w Toruniu, sygn. 7207.

${ }^{3}$ Na temat J.H. Zerneckego por.: J. Serczyk, Zernecke Jacob Heinrich, [w:] Toruński stownik biograficzny (dalej cyt. TSB), red. K. Mikulski, t. 1, Torun 1998, s. 259-261. 
Drewniany strop sieni w kamienicy przy ul. Żeglarskiej 16 został całkowicie pokryty dekoracją malarską wykonaną w technice temperowej. Jest to kompozycja iluzjonistyczna, mająca na celu sprawienie wrażenia zatarcia granic między rzeczywistą architekturą a wyobrażeniem malarskim. Centralną jej część zajmuje scena figuralna ujęta malarską imitacją rzeźbionych, ośmiokątnych ram. Warto zaznaczyć, że jest to największe zidentyfikowane dotychczas takie przedstawienie zdobiące stropy w pomieszczeniach toruńskich kamienic - pozostałe realizacje pokryte są w głównej mierze dekoracją ornamentalną ${ }^{4}$. W czterech narożnikach omawianego stropu znajdują się tonda z puttami podtrzymującymi kosze z kwiatami i owocami (il. 1), natomiast na osi góra-dół tonda $\mathrm{z}$ portretami stylizowanymi na rzeźbione popiersia. Po bokach głównej sceny umieszczono dwie pary aniołów ustawionych antytetycznie (il. 2).

Główne przedstawienie na stropie to alegoria Prawda córka Czasu, znana też jako Prawda uratowana przez Chronosa przed atakiem Zawiści i Niezgody (il. 3). Scena rozgrywa się na tle nieba spowitego niewielkimi chmurami o złotawym odcieniu. W centrum znajduje się naga postać kobieca o bardzo jasnej karnacji, symbolizująca Prawdę. Unoszona jest ku górze przez uskrzydlonego mężczyznę - Chronosa, uosabiającego czas (il. 4). Towarzyszy im putto trzymające w rękach sierp oraz uroborosa, czyli węża pożerającego swój własny ogon i jednocześnie się odradzającego, symbolizującego nieskończoność. Sierp z kolei, obok kosy, był jednym z atrybutów Kronosa, który według mitu obciął jądra swojemu ojcu Uranosowi, a na skutek gry słów utożsamiany był niekiedy z Chronosem-Czasem ${ }^{5}$. Poniżej, w schematycznie oddanej strefie ziemskiej, ukazano dwie siedzące postacie kobiece. Po lewej stronie wyobrażona została Zawiść, przedstawiona jako brzydka, zezowata starucha ubrana $\mathrm{w}$ rdzawą szatę, $\mathrm{z}$ wężami w rozczochranych

\footnotetext{
${ }^{4}$ Innym dziełem w tak dużym formacie jest dekoracja w postaci pejzażu umieszczona na ściance działowej w pokoju na trzecim piętrze domu przy ul. Chełmińskiej 26/28 z 1714 r. - K. Kluczwajd, J. Tylicki, Sztuka nowożytna, [w:] Dzieje sztuki Torunia, Toruń 2009, s. 283, il. 243.

${ }^{5}$ Kronos, [w:] P. Grimal, Stownik mitologii greckiej i rzymskiej, Wrocław-WarszawaKraków 1997, s. 193; Sierp, [w:] J. Hall, Leksykon symboli sztuki Wschodu i Zachodu, Kraków 1997, s. 136.
} 


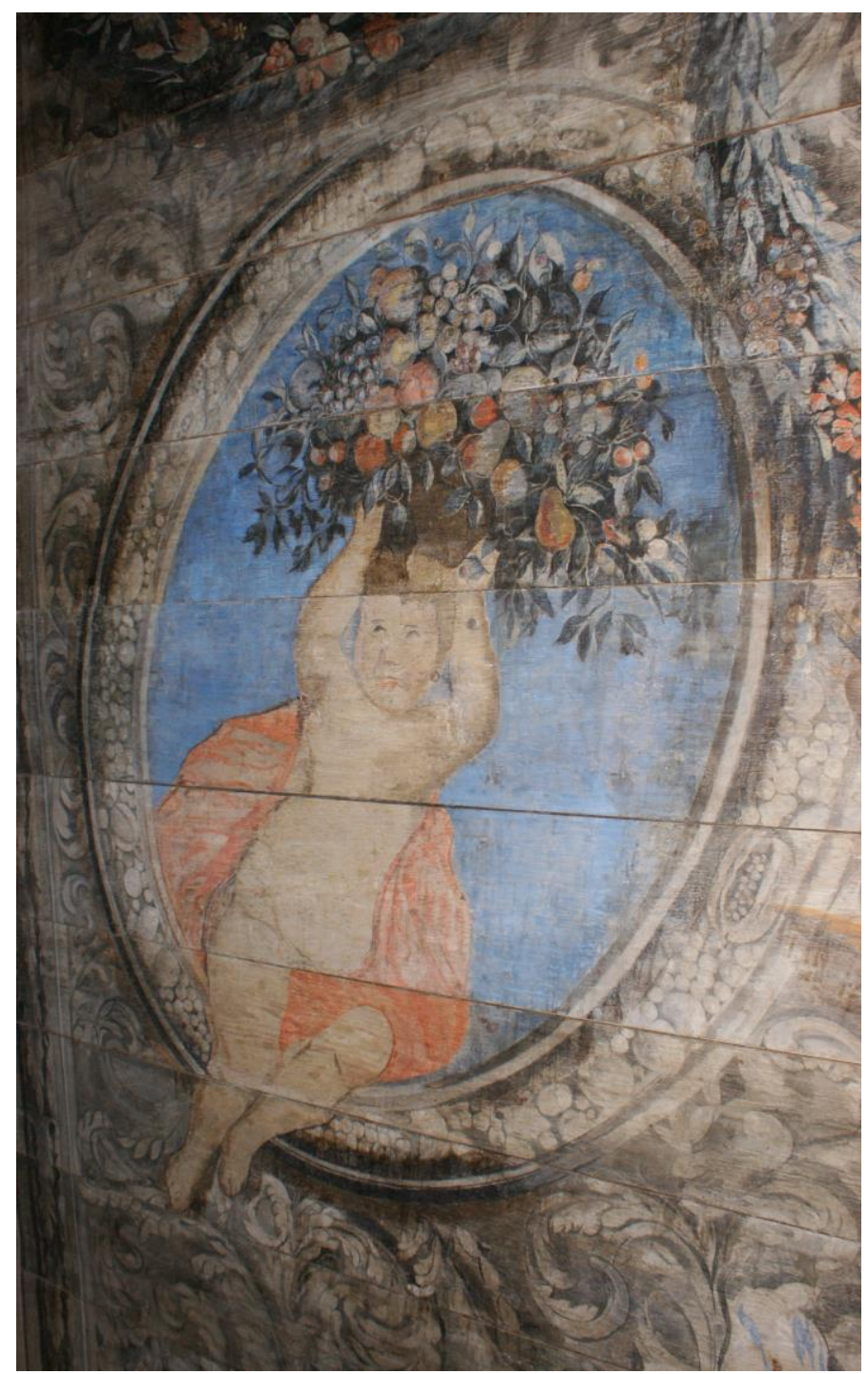

Il. 1. Warsztat Johanna Tiedemana młodszego (atryb.), Putto z koszem, fragment dekoracji stropu sieni w kamienicy przy ul. Żeglarskiej 16 w Toruniu, 1702. Fot. K. Rajman 


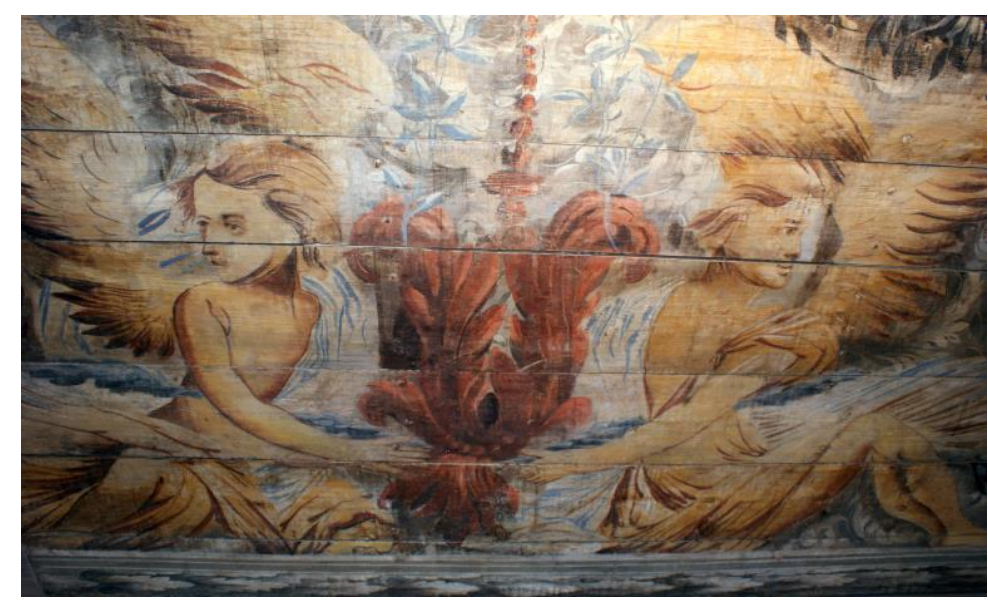

Il. 2. Warsztat Johanna Tiedemana młodszego (atryb.), Para aniołów, fragment dekoracji stropu sieni w kamienicy przy ul. Żeglarskiej 16 w Toruniu, 1702. Fot. K. Rajman

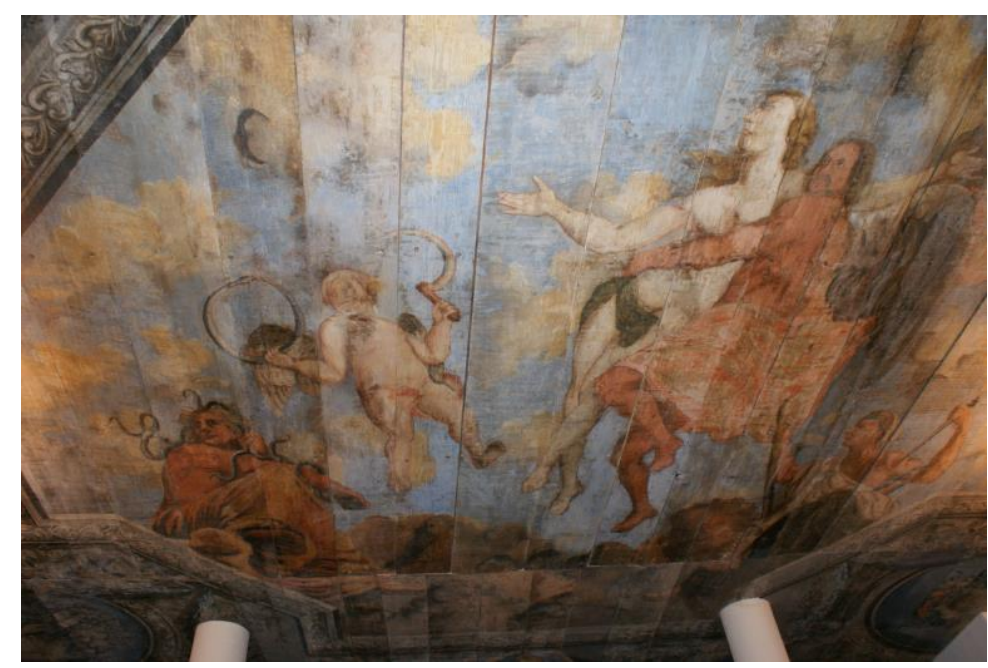

I1. 3. Warsztat Johanna Tiedemana młodszego (atryb.),

Prawda córka Czasu, fragment dekoracji stropu sieni w kamienicy przy ul. Żeglarskiej 16 w Toruniu, 1702. Fot. K. Rajman 


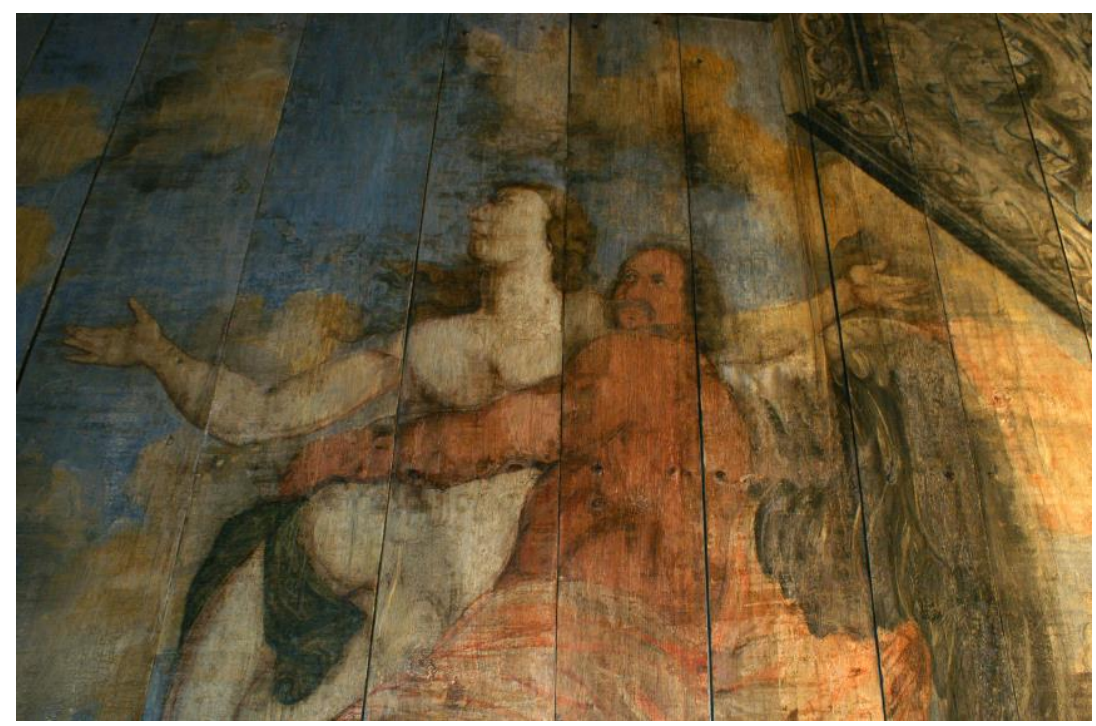

Il. 4. Warsztat Johanna Tiedemana młodszego (atryb.),

Chronos unoszacy Prawdę, fragment dekoracji stropu sieni w kamienicy przy ul. Żeglarskiej $16 \mathrm{w}$ Toruniu, 1702. Fot. K. Rajman

włosach, trzymająca $\mathrm{w}$ dłoni własne serce, którym się posila ${ }^{6}$. Druga z postaci, Niezgoda, trzyma $\mathrm{w}$ lewej ręce sztylet skierowany ostrzem we własną pierś, a w prawej dłoni płonącą pochodnię (il. 5) ${ }^{7}$.

Toruńskie malowidło jest dokładnym powtórzeniem kompozycji Nicolasa Poussina (1594-1665), jednego z najwybitniejszych barokowych malarzy francuskich, przedstawiciela nurtu klasycznego ${ }^{8}$. Niemal całe swoje życie jako artysta spędził w Rzymie, jednak przez krótki okres, na

\footnotetext{
${ }^{6}$ Invidia, [w:] C. Ripa, Iconologia, Venetia 1645, s. 299; Zawiść, [w:] C. Ripa, Ikonologia, Kraków 2004, s. 210.

${ }^{7}$ Według instrukcji Cesare Ripy Niezgoda powinna trzymać jedynie sztylet ( Lis, [w:] C. Ripa, Iconologia, Venetia 1645, s. 157). Płonąca żagiew - obok innych atrybutów - przypisana jest według niego Oszczerstwu (Calunnia, [w:] C. Ripa, Iconologia, Venetia 1645, s. 74) oraz Gniewowi (Ira, [w:] C. Ripa, Iconologia, Venetia 1645, s. 300; Gniew, [w:] C. Ripa, Ikonologia, Kraków 2004, s. 37-38).

${ }^{8}$ H. Keazor, Poussin Nicolas, [w:] Allgemeines Künstlerlexikon. Die Bildenden Künstler aller Zeiten und Völker, Bd. 96: 2017, s. 436-439.
} 


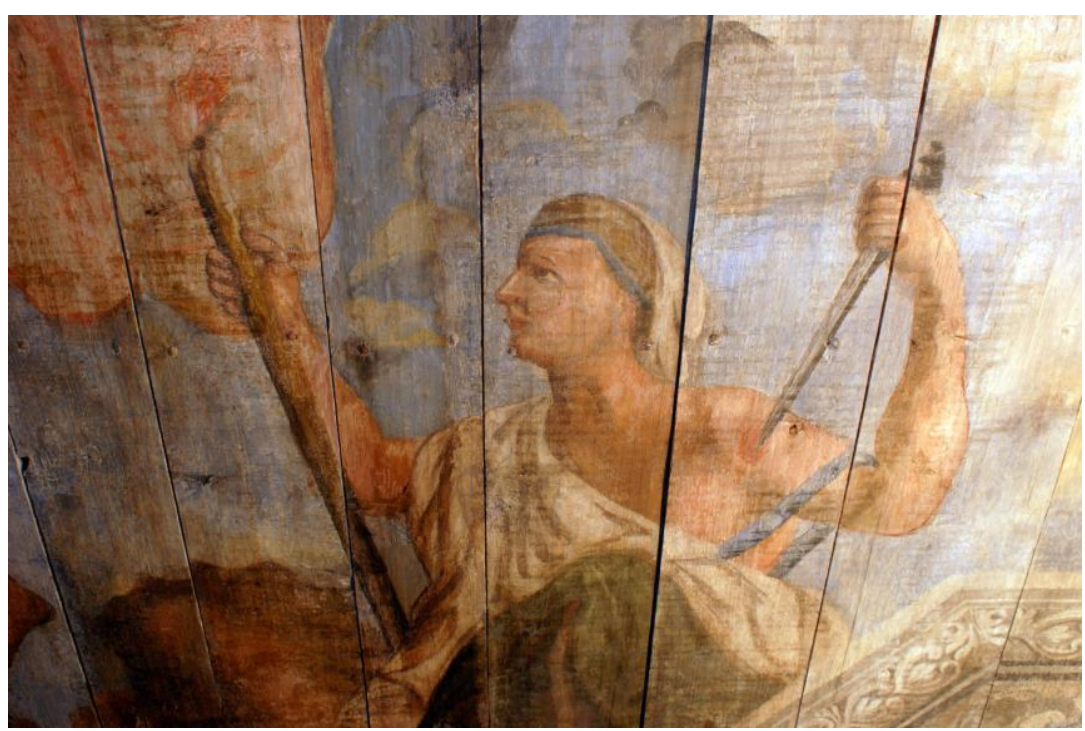

I1. 5. Warsztat Johanna Tiedemana młodszego (atryb.), Niezgoda, fragment dekoracji stropu sieni w kamienicy przy ul. Żeglarskiej 16 w Toruniu, 1702. Fot. K. Rajman

początku lat czterdziestych XVII w. pracował w Paryżu na dworze Ludwika XIII, gdzie otrzymał tytuł pierwszego malarza królewskiego. Wówczas powstał też obraz Prawda uratowana przez Chronosa przed atakiem Zawiści i Niezgody, wykonany w 1641 r. na zlecenie kardynała Richelieu'. Dzieło zamontowane zostało na suficie „grand cabinet”, czyli prywatnego apartamentu w pałacu kardynalskim. Richelieu zmarł w 1642 r. i zgodnie z jego testamentem pałac wraz z całym wyposażeniem przeszedł w posiadanie króla Ludwika XIII. W 1658 r. malowidło przeniesiono do Luwru, zajmowanego już przez młodego Ludwika XIV, gdzie zawisło na stropie Sali Królewskiej. Prawdopodobnie pod koniec XVIII w. zostało zdemontowane, przycięte i wstawione w no-

\footnotetext{
${ }^{9}$ F. Saxl, Veritas filia Temporis, [w:] Philosophy and History. Essays presented to Ernst Cassirer, Oxford 1936, s. 212-215; Exposition Nicolas Poussin, katalog wystawy w Luwrze, oprac. A. Blunt, [Paris] 1960, s. 97-98, nr kat. 63.
} 
we ramy, aby można je było zawiesić na ścianie ${ }^{10}$. Obraz ten znajduje się w kolekcji Luwru do dziś.

Jacob Heinrich Zernecke, który zapewne sam opracował program ikonograficzny dekoracji stropu w swojej kamienicy, naturalnie nie mógł widzieć na własne oczy obrazu znajdującego się w pałacu królewskim w Paryżu. Niewątpliwie znał go za pośrednictwem ryciny - druki ulotne stanowiły wówczas najpopularniejszy nośnik wzorców formalnych i ikonograficznych. Powstało kilka graficznych wersji kompozycji Poussina, wymienić można chociażby miedzioryty Girarda Audrana (1640-1703) i Pietera Schenka I (1660 - ok. 1715) $)^{11}$. Najbliższa toruńskiemu malowidłu wydaje się rycina Bernarda Picarda (1673-1733), według inskrypcji zamieszczonej pod przedstawieniem wykonana na podstawie bezpośredniego oglądu dzieła Poussina (il. 6) ${ }^{12}$. Powstała zatem najpewniej $\mathrm{w}$ połowie lat dziewięćdziesiątych XVII w., gdyż w 1696 r. Picard opuścił rodzinny Paryż i przeniósł się do Niderlandów ${ }^{13}$.

Motyw Prawda córka Czasu (Veritas filia Temporis) rozpropagowany został w kręgu szesnastowiecznych humanistów, ciesząc się stałą popularnością w sztukach plastycznych przez całą epokę nowożytną ${ }^{14}$. U jego źródeł stoi sentencja Veritatem Temporis filiam zacytowana przez Gelliusza, rzymskiego erudytę z drugiej połowy II w. n.e., w jego zbiorze przemyśleń i wypisów z różnych lektur zatytułowanym Noce attyckie (księga XII, rozdział 11) ${ }^{15}$. Autorem myśli miał być grecki poeta,

\footnotetext{
${ }^{10}$ A. Blunt, Poussin Studies VI: Poussin's Decoration of the Long Gallery in the Louvre, The Burlington Magazine, vol. XCIII, no. 585, December 1951, s. 369-377, tu: s. 370 .

${ }^{11} \mathrm{C}$. Le Blanc, Manuel de l'amateur d'estampes, contenant un dictionnaire des graveurs de toutes les nations, t. 1, Paris 1854, s. 94, nr 101; Hollstein's Dutch and Flemish etchings, engravings and woodcuts ca. 1450-1700, vol. 25: Pieter Schenck, oprac. G. S. Keyes, Amsterdam 1981, s. 78, nr 366.

${ }^{12} \mathrm{C}$. Le Blanc, Manuel de l'amateur d'estampes, contenant un dictionnaire des graveurs de toutes les nations, t. 3, Paris 1857, s. 193, nr 465.

${ }^{13}$ U. Heise, Picard Bernard, [w:] Allgemeines Künstlerlexikon. Die Bildenden Künstler aller Zeiten und Völker, Bd. 95: 2017, s. 390-391.

${ }^{14} \mathrm{Na}$ ten temat por. F. Saxl, Veritas filia Temporis, s. 197-222.

${ }^{15}$ Aulus Gellius, Noctes atticae, Coloniae 1537, s. 429-430; F. Saxl, Veritas filia Temporis, s. 200.
} 


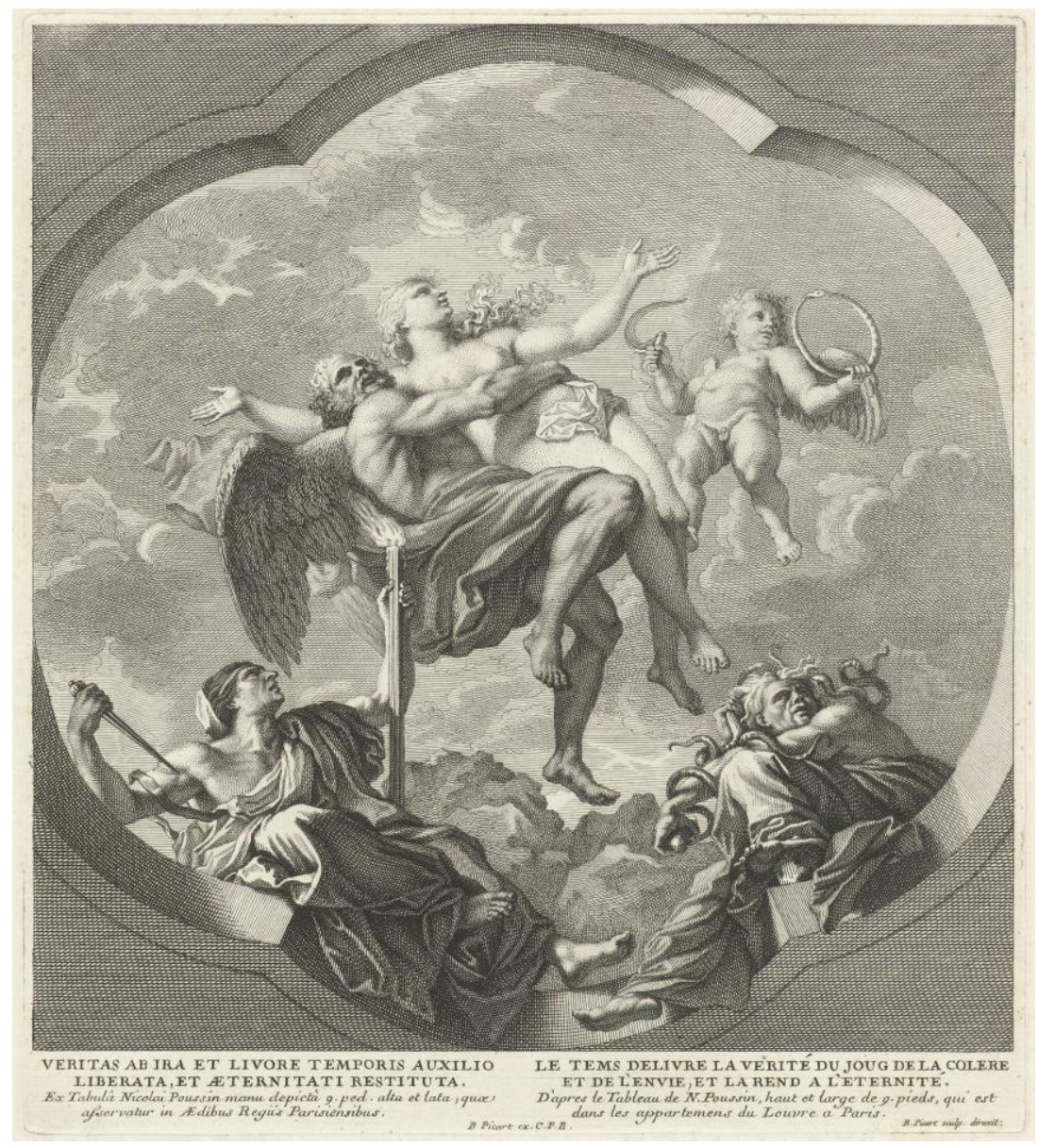

Il. 6. Bernard Picard na podstawie Nicolasa Poussina, Prawda córka Czasu, miedzioryt/akwaforta, Paryż, 1692-1696. Fot. ze zbiorów Rijksmuseum w Amsterdamie, http://hdl.handle.net/10934/RM0001.COLLECT.297876 
którego imienia Gelliusz niestety nie pamięta ${ }^{16}$. Sentencja - z powołaniem na Noce attyckie - pojawiła się w wydanym w 1508 r. Adagiorum chiliades Erazma z Rotterdamu: zbiorze ponad trzech tysięcy przysłów antycznych opatrzonych komentarzami niderlandzkiego humanisty $^{17}$. To prawdopodobnie stąd zaczerpnięto inspirację do wersji obrazowej. Jednym z najstarszych znanych przykładów jest znak weneckiego drukarza i wydawcy Marcolina da Forlì, użyty po raz pierwszy w 1536 r., a skomponowany przez pisarza Pietro Aretino ${ }^{18}$. Chronos wyrywa w nim Prawdę z rąk interpretowanej jako Oszczerstwo (Calumnia) postaci ze smoczym ogonem, trzymającej ją za włosy i uderzającej wężami ${ }^{19}$. W następnych latach rozwijano tę ideę, umieszczając na przedstawieniach Veritas filia Temporis personifikacje innych występków dążących do ukrycia Prawdy: Zawiści, Niezgody i Oszczerstwa ${ }^{20}$. Warto podkreślić, że w wersji Poussina Zawiść oddana została dokładnie według instrukcji zawartych w Ikonologii Cesarego Ripy, a więc bezsprzecznie najpopularniejszym źródle ikonograficznym nowożytności ${ }^{21}$. Atrybuty drugiej kobiety stanowią z kolei połączenie Niezgody (sztylet skierowany we własną pierś) i Oszczerstwa (płonąca pochodnia) ${ }^{22}$.

\footnotetext{
${ }^{16}$ Mogło w tym wypadku chodzić o Menandra (342-291 p.n.e.), autora podobnej sentencji, zacytowanej w łacińskiej wersji Tempus in lucem tandem veritatem trahit (Czas ostatecznie doprowadzi prawdę do światła) w obszernych komentarzach Charlesa Mignaulta do dzieła Emblemata Andrei Alciata - Omnia Andreae Alciati V.C. Emblemata. Cum commentariis, quibus emblematum detecta origine, dubia omnia, et obscura illustrantur, Parisus 1602, s. 194. Por.: A. Pigler, Barockthemen: eine Auswahl von Verzeichnissen zur Ikonographie des 17. und 18. Jahrhunderts, Bd. 2, Budapest 1974, s. 524.

${ }^{17}$ Desiderius Erasmus, Adagiorum chiliades tres, ac centuriae fere totidem, Venetiis 1508 , k. 144r, nr CCCXI.

${ }^{18}$ F. Saxl, Veritas filia Temporis, s. 197-202.

${ }^{19}$ Ibid., s. 201.

${ }^{20} \mathrm{Na}$ przykład: Hadrianus Junius, Emblemata, Antverpiae 1565, s. 59, emblemat LIII; por. D. Gordon, „Veritas Filia Temporis”: Hadrianus Junius and Geoffrey Whitney, Journal of the Warburg and Courtauld Institutes, vol. 3: 1940, no. 3/4, s. 228-240, tu: s. 236-238.

${ }^{21} \mathrm{O}$ popularności dzieła Ripy i zamieszczonych w nim opisów poszczególnych personifikacji świadczy chociażby fakt, że autor toruńskiego malowidła, choć niewątpliwie posiłkował się jedynie czarno-białą ryciną, przedstawił Zawiść w szatach o rdzawym kolorze, a więc zgodnie z wytycznymi z Ikonologii.

${ }^{22}$ Lis, [w:] C. Ripa, Iconologia, Venetia 1645, s. 157; Calunnia, ibid., s.74.
} 
Cztery popiersiowe portrety umieszczone na osi kompozycji przedstawiają dwie pary małżeńskie z rodziny Zernecke (il. 7). Pierwszą z nich tworzą Johann oraz Christina $\mathrm{z}$ domu Müller, rodzice Jacoba Heinricha, którzy zapewne opłacili dekorację domu syna, będącego wówczas dopiero u progu swojej kariery. Druga to sam Jacob Heinrich i Concordia z domu Stannicke, poślubiona przez niego w Gdańsku 1 V 1702 r. Miesiąc miodowy nowożeńcy spędzili w Gdańsku, do Torunia przybyli 6 czerwca tego roku ${ }^{23}$. Dekoracja stropu w toruńskiej kamienicy musiała powstać zatem po tej dacie.

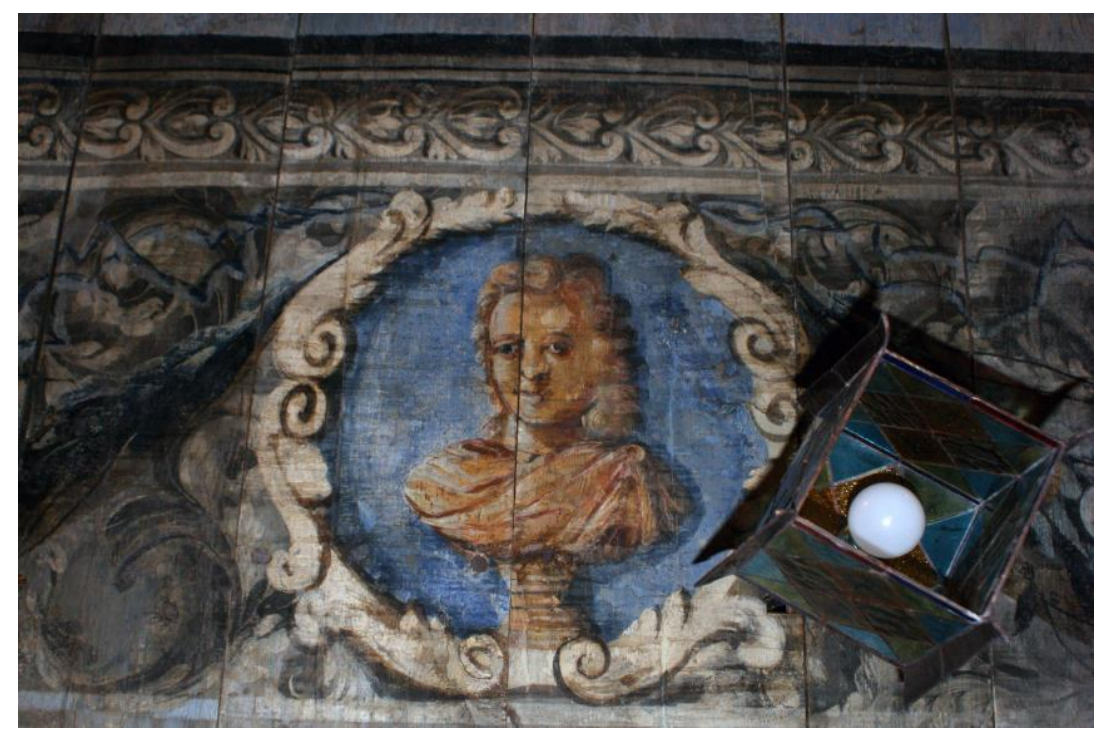

Il. 7. Warsztat Johanna Tiedemana młodszego (atryb.),

Popiersie Jacoba Heinricha lub Johanna Zerneckego, fragment dekoracji stropu sieni w kamienicy przy ul Żeglarskiej 16 w Toruniu, 1702. Fot. K. Rajman

${ }^{23}$ W.F.H. Zernecke, Geschichte der Familie Zernecke, Bd. 2: Jacob Heinrich Zernecke. Bürgermeister und Chronist von Thorn (1672-1741), Riesenburg Westpr. 1909, s. 29. 
Na podstawie analizy źródeł archiwalnych można przypuścić, że wykonawcą malowideł był Johann (III) Tiedeman młodszy. Należał on do artystycznej rodziny: oprócz niego malarstwem zajmowali się także jego ojciec Johann starszy i brat Daniel. Inny z braci, Michael, był ławnikiem nowomiejskim. Dzieje rodziny związane były z Toruniem od około 1631 r. Dnia 28 maja tego roku Johann (I) Tiedeman, czeladnik stolarski, ożenił się z Anną, córką Johanna Jäschke, toruńskiego rzeźnika $^{24}$. Anna ochrzczona została 19 VI 1610 r. w kościele św. Jakuba na Nowym Mieście ${ }^{25}$; zmarła zapewne krótko przed 9 II 1634 r., kiedy opłacony został jej pogrzeb ${ }^{26}$. Z tego małżeństwa urodziło się trzech synów: Peter (ok. 1631) oraz bliźnięta Johann i Marcus (chrz. 7 V $1633^{27}$ ). Marcus zmarł zapewne w dzieciństwie, natomiast Peter i Johann 9 IX 1641 r. zapisani zostali do Gimnazjum Toruńskiego jako synowie Johanna, strażnika miejskiego ${ }^{28}$. Nie zdołał on uzyskać obywatelstwa miejskiego jako stolarz, więc około 1640 r. wstąpił do milicji miejskiej i pełnił funkcję strażnika przy bramach miejskich. Zapewne z tego powodu przeniósł się też na Nowe Miasto. Około $1637 \mathrm{r}$. ożenił się ponownie, $\mathrm{z}$ nieznaną $\mathrm{z}$ nazwiska Anną, z którą miał co najmniej czworo dzieci: Simona (chrz. 25 X 1637 192 ), Annę (chrz. 6 VI $1640^{30}$ ), Reginę (chrz. 20 VI $1641^{31}$ ) i dziecko nieznanej płci (chrz. 31 XII $1643^{32}$ ). Anna młodsza została pochowana 2 VII $1659 \mathrm{r}^{33}$; pozo-

\footnotetext{
${ }^{24}$ Archiwum Akt Dawnych Diecezji Toruńskiej (dalej cyt. AADDT), Parafia pw. Wniebowzięcia NMP (dalej cyt. NMP) i Parafia pw. św. Wawrzyńca w Toruniu, sygn. AD001: Księga ślubów 1600-1755, s. 96.

${ }^{25}$ Archiwum Państwowe w Toruniu (dalej cyt. APT), Ewangelicka Gmina Wyznaniowa Nowomiejska w Toruniu (dalej cyt. EGWN), sygn. 76: „Tauf Register” [16061702], s. 37.

${ }^{26}$ APT, Ewangelicka Gmina Wyznaniowa św. Jerzego w Toruniu (dalej cyt. EGWJ), sygn. 131: „Rechnungen der Kirche S: Georgi. Angefangen Anno 1592 [bis 1666], s. 405.

${ }^{27}$ AADDT, NMP, sygn. AA001: Księga chrztów 1616-1676, s. 105.

${ }^{28}$ Metryka uczniów Toruńskiego Gimnazjum Akademickiego 1600-1817, wyd. Z. H. Nowak, J. Tandecki, t. 1-2, Toruń 1997-1998 (dalej cyt. MUTGA), nr 4077, 4078.

${ }^{29}$ AADDT, NMP, sygn. AA001, s. 143.

${ }^{30}$ APT, Ewangelicka Gmina Wyznaniowa Staromiejska w Toruniu, sygn. 20a: Księga chrztów, ślubów i zgonów 1630-1644, s. 164.

${ }^{31}$ Ibid., s. 180.

${ }^{32}$ Ibid., s. 219.

${ }^{33}$ APT, EGWN, sygn. 77: Księga ślubów i zgonów z lat 1651-1793, s. 415.
} 
stałe dzieci z tego małżeństwa zmarły zapewne w dzieciństwie. Nieznane są też dalsze losy Petera, ucznia Gimnazjum Toruńskiego; być może wyemigrował z Torunia. Johann (I) zmarł w 1659 r. i został pochowany 15 września tego roku ${ }^{34}$. Wdowa po nim, Anna, żyła jeszcze do końca $1681 \mathrm{r}$. (poch. 21 XII 1681) ${ }^{35}$. O statusie społecznym rodziny może świadczyć aktywność małżonków w świadkowaniu przy chrztach. Johann proszony był o to jedynie trzykrotnie, pod koniec życia, przez przedstawicieli plebsu: Martina Brelauwa (syn Paul, chrz. 21 I $1658^{36}$ ), Georga Gillaua (syn Martin, chrz. 30 X 1657) ${ }^{37}$ oraz Bartholomeusa Lewinga $z$ podtoruńskiej wsi (syn Bartholomeus, chrz. 8 VIII 1658) ${ }^{38}$, natomiast żadna $\mathrm{z}$ żon Johanna nie została odnotowana jako chrzestna.

Pierwszym $\mathrm{z}$ toruńskich malarzy w rodzinie Tiedemanów był Johann (II), określany w literaturze przedmiotu jako „starszy”. Jak już wspomniano, ochrzczony został $7 \mathrm{~V} 1633 \mathrm{r}^{39}$, a w wieku ośmiu lat zapisano go do Toruńskiego Gimnazjum Akademickiego, gdzie kontynuował edukację być może aż do 1649 r. Naukę rzemiosła rozpoczął w malarskim warsztacie toruńskiego mistrza Samuela Nähma (Nehma) w wieku 16 lat $^{40}$. Oficjalnie zapisany został na termin w 1649 r. podczas zebrania na kwartał św. Michała (zwyczajowo odbywało się ono około 29 września, kiedy wypada wspomnienie liturgiczne świętego ${ }^{41}$. Pięcioletnią naukę Tiedeman zakończył 13 IV 1654 r. i wyzwolony został wówczas na czeladnika. Prawdopodobnie przez kolejnych kilka lat pracował w Toruniu u tutejszych mistrzów. Z 25 VI 1659 r. pochodzi kolejna wzmianka na jego temat: pobrał wówczas z cechu swój list wyuczenia i uiścił za niego opłatę ${ }^{42}$. Niewątpliwie rozpoczął wówczas

${ }^{34}$ APT, EGWN, sygn. 77, s. 416.

${ }^{35}$ Ibid., s. 466.

${ }^{36}$ APT, EGWN, sygn. 76, s. 544.

${ }^{37}$ Ibid., s. 539.

${ }^{38}$ Ibid., s. 559.

${ }^{39}$ AADDT, NMP, sygn. AA001, s. 105.

${ }^{40}$ Por. B. Dybaś, Nehm Samuel, [w:] Słownik artystów polskich i obcych w Polsce działajacych. Malarze - rzeźbiarze - graficy (dalej cyt. SAP), t. 6, Warszawa 1998, s. 35.

${ }^{41}$ APT, Cech malarzy, rzeźbiarzy i lakierników z Torunia (dalej cyt. Cech malarzy) sygn. 4: Protokollbuch 1621-1732, s. 125. Równocześnie na naukę do S. Nähma wpisany został także Michael Petzold.

${ }^{42}$ APT, Cech malarzy, sygn. 4, s. 135. 
okres wędrówki czeladniczej, obowiązkowej dla każdego przyszłego kandydata na mistrza. Według statutu toruńskiej organizacji przez przynajmniej dwa lata miał zdobywać doświadczenie w warsztatach malarskich na terenie Europy oraz przynajmniej rok przepracować u miejscowego majstra ${ }^{43}$. Szczegóły wędrówki Tiedemana nie są znane. Wiadomo, że w Toruniu odnotowany został ponownie 16 VII $1663 \mathrm{r}^{44}$ Zameldował się wówczas w cechu i wyraził chęć przystąpienia do egzaminu mistrzowskiego, opłacając w tym celu 6 zł. Swój majstersztyk wykonywał w pracowni Michaela Sperbera - gotową pracę przedłożył 6 września tego roku i został wówczas pełnoprawnym członkiem korporacji malarskiej ${ }^{45}$. Taksę mistrzowską wynoszącą $21 \mathrm{zł}$ spłacał w ratach przez kilkanaście miesięcy ${ }^{46}$.

W krótkim czasie po powrocie do Torunia, 12 XI 1663 r. ${ }^{47}$, ożenił się z Sabiną, córką białoskórnika Michaela Vogela. Zmarła ona jednak już w następnym roku (poch. 1 grudnia $^{48}$ ). Było to zapewne jedną z przyczyn tarapatów finansowych Johanna, które opóźniły uzyskanie przez niego statusu obywatela Torunia. Stało się to możliwe dopiero w $1668 \mathrm{r}^{49}$, być może dzięki posagowi, który wniosła jego druga żona, pochodząca z Prabut Anna Unruh, córka Michaela. Ich ślub odbył się w Toruniu $1 \mathrm{~V} 1668 \mathrm{r}^{50} \mathrm{Z}$ tego małżeństwa urodziło się dziewięcioro dzieci, z których czworo zmarło w wieku niemowlęcym: Anna Elisabeth (chrz. $22 \mathrm{X}$ 1676; poch. 23 I $1677^{51}$ ), Jacob (chrz. 30 VI 1680; poch. 14 VII $1680^{52}$ ),

\footnotetext{
${ }^{43}$ Statut cechu malarzy z $1621 \mathrm{r}$., [w:] Statuty toruńskiego rzemiosła artystycznego $i$ budowlanego z XVI-XVIII w., wyd. B. Dybaś, J. Tandecki, M. Farbiszewski, Warszawa-Toruń 1990, s. 112, 113, par. 11.

${ }^{44}$ APT, Cech malarzy, sygn. 4, s. 137.

${ }^{45}$ Ibid.

${ }^{46}$ Ibid., s. 137-139.

${ }^{47}$ APT, EGWN, sygn. 77, s. 37

${ }^{48}$ APT, EGWJ, sygn. 131, s. 581.

${ }^{49}$ A. Semrau, Die Bürgerlisten der Stadt Thorn aus dem 17. Jahrhunderte, T. 2: Die ausländischen Bürger, Mitteilungen des Coppernicus-Vereins für Wissenschaft und Kunst zu Thorn, H. 28: 1920, s. 51.

${ }^{50}$ APT, EGWN, sygn. 77, s. 45.

${ }^{51}$ AADDT, NMP, sygn. AA001, s. 395; APT, EGWJ, sygn. 132: „Kirchen Rechnung zu St: Georgen von der Einnahm und Ausgab” [1667-1735], s. 101.

${ }^{52}$ AADDT, NMP, sygn. AA002: Księga chrztów 1677-1735, s. 15; APT, EGWJ, sygn. 132, s. 126.
} 
Samuel (chrz. 6 V 1685; poch. 15 VI $1685^{53}$ ) oraz Christian (chrz. 25 III 1688; poch. 27 II $1690^{54}$ ). Lata sprawne osiągnęli synowie: Johann (chrz. 31 VII 1669 ${ }^{55}$ ), Michael (chrz. 27 IX 1671 $1^{56}$ ) i Daniel (chrz. 22 X $1676^{57}$ ), a także dwie córki: Elisabeth (chrz. 22 I $1678^{58}$ ) i Maria (chrz. $14 \times 1681^{59}$ ). Warto nadmienić, że starsza z córek 7 VI 1701 r. została wydana za mąż za snycerza Simona Barcka (poch. 3 V 1732), członka toruńskiego cechu malarsko-rzeźbiarskiego ${ }^{60}$. Młodsza Maria 7 X $1704 \mathrm{r}$. poślubiła Christiana Stahna, postrzygacza sukna (zm. po 1733) ${ }^{61}$. Obie siostry zmarły po $1729 \mathrm{r}$.

Tabela 1a. Chrzty, przy których świadkiem był Johann (II) Tiedeman (starszy)

\begin{tabular}{|c|c|c|c|c|c|c|c|}
\hline $\begin{array}{c}\text { Data } \\
\text { chrztu }\end{array}$ & $\begin{array}{c}\text { Nazwisko } \\
\text { dziecka }\end{array}$ & $\begin{array}{c}\text { Imię } \\
\text { dziecka }\end{array}$ & $\begin{array}{c}\text { Imię } \\
\text { ojca }\end{array}$ & $\begin{array}{c}\text { Zawód } \\
\text { ojca }\end{array}$ & $\begin{array}{c}\text { Nazwisko } \\
\text { matki }\end{array}$ & $\begin{array}{c}\text { Imię } \\
\text { matki }\end{array}$ & Źródło \\
\hline 1 & 2 & 3 & 4 & 5 & 6 & 7 & 8 \\
\hline $\begin{array}{c}\text { VIII } \\
1679\end{array}$ & Mohrholt & Anna & Georg & płóciennik & Prübser & Eva & $\begin{array}{c}\text { APT,EGWN, } \\
\text { sygn. 76, } \\
\text { s. 736 }\end{array}$ \\
\hline $\begin{array}{c}5 \\
\text { V } \\
1682\end{array}$ & Behnisch & Gottfried & Gottfried & powroźnik & Rurich & Elisabeth & $\begin{array}{c}\text { APT, EGWN, } \\
\text { sygn. 76, } \\
\text { s. 751 }\end{array}$ \\
\hline $\begin{array}{c}21 \\
\text { V } \\
1688\end{array}$ & Cholewa & Johann & Martin & płóciennik & Logsch & Anna & $\begin{array}{c}\text { APT, EGWN, } \\
\text { sygn. 76, } \\
\text { s. 793 }\end{array}$ \\
\hline $\begin{array}{c}16 \\
\text { X } \\
1689\end{array}$ & Fechner & Andreas & Georg & żołnierz & Berojen & Maria & $\begin{array}{c}\text { APT, EGWN, } \\
\text { sygn. 76, } \\
\text { s. 803 }\end{array}$ \\
\hline
\end{tabular}

\footnotetext{
${ }^{53}$ APT, EGWN, sygn. 76, s. 771; sygn. 77, s. 479.

${ }^{54}$ Ibid., sygn. 76, s. 792; sygn. 77, s. 487.

${ }^{55}$ AADDT, NMP, sygn. AA001, s. 363.

${ }^{56}$ Ibid., s. 375.

${ }^{57}$ APT, EGWN, sygn. 76, s. 703.

${ }^{58}$ AADDT, NMP, sygn. AA002, s. 4.

${ }^{59}$ APT, EGWN, sygn. 76, s. 746.

${ }^{60}$ B. Łyczak, Toruński cech rzeźbiarski i snycerka na obszarze jego oddziaływania w latach 1695-1793, Warszawa 2018, s. 43.

${ }^{61}$ APT, EGWN, sygn. 77, s. 114.
} 


\begin{tabular}{|c|c|c|c|c|c|c|c|}
\hline 1 & 2 & 3 & 4 & 5 & 6 & 7 & 8 \\
\hline $\begin{array}{c}23 \\
\text { IV } \\
1691\end{array}$ & Cender & Anna & Błażej & plebs & $\mathrm{N}$ & Dorota & $\begin{array}{c}\text { AADDT, } \\
\text { Jakub, } \\
\text { sygn. AA001, } \\
\text { s. 87 }\end{array}$ \\
\hline $\begin{array}{c}17 \\
\text { V } \\
1691\end{array}$ & Beyer & $\begin{array}{c}\text { Georg } \\
\text { Friedrich }\end{array}$ & $\begin{array}{c}\text { Johann } \\
\text { Georg }\end{array}$ & żołnierz & $\mathrm{N}$ & Anna & $\begin{array}{c}\text { APT, EGWN, } \\
\text { sygn. 76, } \\
\text { s. 815 }\end{array}$ \\
\hline $\begin{array}{c}20 \\
\text { VII } \\
1693\end{array}$ & Fechner & Johann & Georg & żołnierz & Berojen & Maria & $\begin{array}{c}\text { APT, EGWN, } \\
\text { sygn. 76, } \\
\text { s. 831 }\end{array}$ \\
\hline $\begin{array}{c}28 \\
\text { VIII } \\
1701\end{array}$ & Wolff & Johann & Jacob & powroźnik & Tierselt & Elisabeth & $\begin{array}{c}\text { APT, EGWN, } \\
\text { sygn. 78, } \\
\text { s. 12 }\end{array}$ \\
\hline
\end{tabular}

Tabela 1b. Chrzty, przy których świadkiem była Anna Tiedeman

\begin{tabular}{|c|c|c|c|c|c|c|c|}
\hline $\begin{array}{c}\text { Data } \\
\text { chrztu }\end{array}$ & $\begin{array}{c}\text { Nazwisko } \\
\text { dziecka }\end{array}$ & $\begin{array}{c}\text { Imię } \\
\text { dziecka }\end{array}$ & $\begin{array}{c}\text { Imię } \\
\text { ojca }\end{array}$ & $\begin{array}{c}\text { Zawód } \\
\text { ojca }\end{array}$ & $\begin{array}{c}\text { Nazwisko } \\
\text { matki }\end{array}$ & $\begin{array}{c}\text { Imię } \\
\text { matki }\end{array}$ & Źródło \\
\hline $\begin{array}{c}14 \\
\text { VIII } \\
1678\end{array}$ & Zeyfert & Marianna & Jan & $\begin{array}{c}\text { szewc } \\
\text { partacz }\end{array}$ & $\mathrm{N}$ & Ewa & $\begin{array}{c}\text { AADDT, Jan, } \\
\text { sygn. AA003, } \\
\text { s. 28 }\end{array}$ \\
\hline $\begin{array}{c}20 \\
\text { I } \\
1686\end{array}$ & Hoffman & Dorothea & Johann & malarz & Krieckent & Anna & $\begin{array}{c}\text { AADDT,NMP } \\
\text { sygn. AA002, } \\
\text { s. 41 }\end{array}$ \\
\hline $\begin{array}{c}9 \\
\text { V } \\
1688\end{array}$ & Grosner & Anna & Friedrich & $\begin{array}{c}\text { przedmie- } \\
\text { stek }\end{array}$ & $\mathrm{N}$ & Elisabeth & $\begin{array}{c}\text { APT, EGWJ, } \\
\text { sygn. 67, } \\
\text { s. 143 }\end{array}$ \\
\hline $\begin{array}{c}3 \\
\text { X } \\
1690\end{array}$ & Falkowski & Jadwiga & Jan & plebs & $\mathrm{N}$ & Marianna & $\begin{array}{c}\text { AADDT, } \\
\text { Jakub, } \\
\text { sygn. AA001, } \\
\text { s. 81 }\end{array}$ \\
\hline $\begin{array}{c}8 \\
\text { X } \\
1690\end{array}$ & Cholewa & Michael & Martin & płóciennik & Logsch & Anna & $\begin{array}{c}\text { APT, EGWN, } \\
\text { sygn. 76, } \\
\text { s. 809 }\end{array}$ \\
\hline $\begin{array}{c}20 \\
\text { III } \\
1695\end{array}$ & Fabiańczyk & Catharina & Simon & mokrzanin & N & Catharina & $\begin{array}{c}\text { APT, EGWJ, } \\
\text { sygn. 67, } \\
\text { s. 153 }\end{array}$ \\
\hline $\begin{array}{c}13 \\
\text { VI } \\
1702\end{array}$ & Fabiańczyk & Johann & Simon & mokrzanin & N & Dorothea & $\begin{array}{c}\text { APT, EGWJ, } \\
\text { sygn. 67, } \\
\text { s. 171 }\end{array}$ \\
\hline
\end{tabular}


Johann (II) był świadkiem przy siedmiu chrztach luteranów oraz jednym chrzcie katolickim, z kolei jego żona Anna świadkowała siedmiokrotnie: dla piątki dzieci luteranów i dwójki katolików. Rodzice dzieci trzymanych przez małżonków do chrztu należeli do najuboższej grupy pospólstwa (6) i plebsu (9). Biorąc ten wskaźnik pod uwagę, Tiedemanów można więc zaliczyć do uboższej warstwy pospólstwa. Liczba trzymanych do chrztu dzieci świadczy jednak o pewnej estymie, jaką musieli się cieszyć wśród najuboższych mieszkańców Torunia. Dla swojego potomstwa starali się, zgodnie z panującymi wówczas zwyczajami, dobierać chrzestnych z wyższych warstw.

Tabela 2. Świadkowie chrztów dzieci Johanna (II) Tiedemana (starszego)

\begin{tabular}{|c|c|c|c|c|}
\hline $\begin{array}{c}\text { Imię } \\
\text { dziecka }\end{array}$ & $\begin{array}{c}\text { Data } \\
\text { chrztu }\end{array}$ & Świadek & Zawód & Źródło \\
\hline 1 & 2 & 3 & 4 & 5 \\
\hline Johann & 31 VII 1669 & Antonius Stadtländer & balwierz & $\begin{array}{c}\text { AADDT, NMP, } \\
\text { sygn. AA001, } \\
\text { s. } 363 \\
\end{array}$ \\
\hline Johann & 31 VII 1669 & Greger Schönknecht & kupiec & ibid. \\
\hline Johann & 31 VII 1669 & Anna Kronenberger & żona kupca & ibid. \\
\hline Michael & 27 IX 1671 & Nicolaus Bergman & postrzygacz sukna & $\begin{array}{c}\text { AADDT, NMP, } \\
\text { sygn. AA001, } \\
\text { s. } 375 \\
\end{array}$ \\
\hline Michael & 27 IX 1671 & Jacob Knoll & iglarz & ibid. \\
\hline Michael & 27 IX 1671 & Anna Tülcke & żona bednarza & ibid. \\
\hline Daniel & 2 IV 1674 & Michael Althofer & siodlarz & $\begin{array}{l}\text { APT, EGWN, } \\
\text { sygn. } 76, \\
\text { s. } 703\end{array}$ \\
\hline Daniel & 2 IV 1674 & $\begin{array}{l}\text { Antonius Günther } \\
\text { Schlieman }\end{array}$ & balwierz & ibid. \\
\hline Daniel & 2 IV 1674 & Elisabeth Wolff & żona powroźnika & ibid. \\
\hline $\begin{array}{c}\text { Anna } \\
\text { Elisabeth }\end{array}$ & $22 \times 1676$ & $\begin{array}{l}\text { Friedrich Martin } \\
\text { Wächter }\end{array}$ & powroźnik & $\begin{array}{c}\text { AADDT, NMP, } \\
\text { sygn. AA001, } \\
\text { s. } 395\end{array}$ \\
\hline $\begin{array}{c}\text { Anna } \\
\text { Elisabeth }\end{array}$ & $22 \times 1676$ & Elisabeth Gärtchen & żona stolarza & ibid. \\
\hline $\begin{array}{c}\text { Anna } \\
\text { Elisabeth }\end{array}$ & $22 \times 1676$ & Elisabeth Hugabe & $\mathrm{N}$ & ibid. \\
\hline
\end{tabular}




\begin{tabular}{|c|c|c|c|c|}
\hline 1 & 2 & 3 & 4 & 5 \\
\hline Elisabeth & 22 I 1678 & Samuel Vierhoff & mydlarz & $\begin{array}{c}\text { AADDT, NMP, } \\
\text { sygn. AA002, } \\
\text { s. 4 }\end{array}$ \\
\hline Elisabeth & 22 I 1678 & Anna Kloßman & żona kupca & ibid. \\
\hline Elisabeth & 22 I 1678 & Constantia Hempel & żona kupca & ibid. \\
\hline Jacob & 30 VI 1680 & Elias Rücker & stolarz & $\begin{array}{c}\text { AADDT, NMP, } \\
\text { sygn. AA002, } \\
\text { s. 15 }\end{array}$ \\
\hline Jacob & 30 VI 1680 & Gottfried Bersch & N & ibid. \\
\hline Jacob & 30 VI 1680 & Maria Vogel & żona kaletnika & ibid. \\
\hline Maria & 14 X 1681 & Stephan Held & piwowar & $\begin{array}{c}\text { APT, EGWN, } \\
\text { sygn. 76, } \\
\text { s. 746 }\end{array}$ \\
\hline Maria & 14 X 1681 & Elisabeth Preuß & wdowa po balwierzu & ibid. \\
\hline Maria & 14 X1681 & Catharina Wegner & żona kupca & ibid. \\
\hline Samuel & 6 V 1685 & Johann Adam Seidel & kupiec & $\begin{array}{c}\text { APT, EGWN, } \\
\text { sygn. 76, } \\
\text { s. 771 }\end{array}$ \\
\hline Samuel & 6 V 1685 & Heinrich Strömming & kupiec & ibid. \\
\hline Samuel & 6 V 1685 & Regina Sachtleben & żona kupca & ibid. \\
\hline Christian & 25 III 1688 & Wentzel Seidelman & zegarmistrz & $\begin{array}{c}\text { APT, EGWN, } \\
\text { sygn. 76, } \\
\text { s. 792 }\end{array}$ \\
\hline Christian & 25 III 1688 & Andreas Teßmer & cejgmacher & ibid. \\
\hline Christian & 25 III 1688 & Anna Maria Hoffman & żona sukiennika & ibid. \\
\hline
\end{tabular}

Wśród 27 świadków przy chrztach ich dzieci wystąpiło tylko dwóch nieobywateli. Znalazło się tam jedenaście osób, które możemy zaliczyć do elity społecznej miasta: ośmiu kupców i ich żony, bogaty piwowar, cejgmacher oraz żona sukiennika, ponadto dziewięciu przedstawicieli bogatego pospólstwa (balwierze, iglarz, siodlarz, żona bednarza, zegarmistrz, mydlarz) i pięciu przedstawicieli rzemiosł uboższych (powroźnicy, stolarze, kaletnik). Dobór świadków do chrztów trojga najmłodszych dzieci świadczy o pewnym wzroście statusu społecznego rodziny w latach osiemdziesiątych XVII w.

Tiedeman w latach 1663-1680 mieszkał na Starym Mieście. W 1681 r. przeniósł się na Nowe Miasto, gdzie kupił kamienicę przy ul. Sukien- 
niczej (dziś nr 16); tam też miał swoją pracownię. W jego warsztacie przebywało na nauce dziewięciu chłopców: Fridrich Teschner (syn pastora ze Wschowy, Melchiora Teschnera, zapisany 2 I 1680 na pięć lat, brak informacji o wyzwolinach), Jacob Stürzenbecher (zapisany 2 I 1680 na pięć lat, usunięty z nauki w 1681), syn Johann (zapisany 3 VII 1684, wyzwolony w 1689), syn Daniel (zapisany 17 X 1689, wyzwolony 11 V 1694), syn Michael (zapisany 11 VII 1691, wyzwolony 1 X tego roku), Jacob Panneck (Pennig; zapisany 11 V 1694 na sześć lat liczonych od 3 stycznia tego roku, odszedł z nauki $30 \mathrm{~V} 1697$ nie otrzymawszy listu wyuczenia), Christian Meldter (Milter; zapisany $11 \mathrm{~V}$ 1694 przez innego toruńskiego mistrza, Johanna Hoffmanna, przejęty po jego śmierci przez Tiedemana i wyzwolony 19 VIII 1699), niewymieniony z nazwiska uczeń (zapisany 6 X 1700 na sześć lat liczonych od kwartału św. Jana 1700, brak informacji o wyzwolinach) oraz Valtin Thomes (zapisany 28 I 1701 na pięć lat, brak informacji o wyzwolinach ${ }^{62}$. Dnia 14 II 1699 r. czeladnik o imieniu Peter został ukarany finansowo przez cech, a opłatę wniósł w jego imieniu Tiedeman, zapewne wówczas go zatrudniający ${ }^{63}$. Inny czeladnik, George Glynski, 6 IV 1695 r. miał przejść do warsztatu Tiedemana po 14 dniach spędzonych u Hioba Heydelmanna, jednak bez wiedzy mistrza udał się do Chełmna, gdzie pracował u partacza ${ }^{64}$. Ponadto od 29 XII 1681 r. Johann Hoffmann odbywał w warsztacie Tiedemana tzw. Mutjahr, a więc obowiązkową roczną praktykę dla czeladnika chcącego podejść do egzaminu mistrzowskiego ${ }^{65}$. Tiedeman pełnił też $\mathrm{w}$ cechu funkcje podstarszego (od 14 VIII 1676, na starszego wybrano wówczas Georga Koyego) oraz starszego (od 11 VII 1691 i od 5 X 1695 do 11 XI 1696) ${ }^{66}$. W księdze protokołów organizacji odnotowano także okazjonalne opóź-

${ }^{62}$ APT, Cech malarzy, sygn. 4, s. 147, 148, 150, 157, 163, 167, 168, 171, 185, 190, 193, 198; B. Dybaś, Milter Christian, SAP, t. 5, Warszawa 1993, s. 569; B. Dybaś, Panneck Hans Jacob, SAP, t. 6, Warszawa 1998, s. 421.

${ }^{63}$ APT, Cech malarzy, sygn. 4, s. 188.

${ }^{64}$ Ibid., s. 176; B. Dybaś, Glynski Georg, SAP, Uzupełnienia i sprostowania do t. 2, Warszawa 1993, s. 15.

${ }^{65}$ APT, Cech malarzy, sygn. 4, s. 151; B. Dybaś, Hoffmann Johann, SAP, Uzupełnienia i sprostowania do t. 3, Warszawa 1993, s. 8.

${ }^{66}$ APT, Cech malarzy, sygn. 4, s. 142, 143, 166, 179, 183. 
nienia w opłacaniu przez malarza składek kwartalnych: po raz pierwszy 23 VI 1698 r., a w następnych latach zdarzało mu się to regularnie $^{67}$. Ponadto 12 VIII 1699 r. pobrał z cechu farby o wartości 6 zł 12 gr, które spłacił dopiero 24 IV 1700 r. Może to świadczyć o nienajlepszej kondycji finansowej Tiedemana w tym czasie. Po raz ostatni odnotowany został w księdze cechowej 26 III 1704 r., gdy ponownie zalegał ze składką kwartalną ${ }^{68}$. Malarz zmarł w następnym roku, pogrzeb odbył się 13 lutego $^{69}$. Jego żona Anna pochowana została 19 VIII $1707 \mathrm{r}^{70}$

Jedynym pewnym dziełem warsztatu Johanna Tiedemana starszego jest dekoracja stropu w kościele w Górsku, zrealizowana w 1694 r. na zlecenie pastora Heinricha Prochnaua (il. 8). Według przekazu Bernharda Schmida, sygnatura malarza widniała na scenie Pokłonu pasterzy i czytelna była jeszcze podczas prac konserwatorskich w $1911 \mathrm{r}^{71}$ Warto odnotować, że mistrz zapewne umieścił w rogu kompozycji swój autoportret, nadając ludzką twarz siedzącemu przy żłobie psu.

Pracowni Tiedemana starszego przypisywano ponadto kilka dzieł w Toruniu i okolicach; atrybucje te są jednak w dużej mierze wątpliwe. Należy przy tym zaznaczyć, że analizy stylistyczno-porównawczej nie ułatwia stan zachowania niektórych prac oraz silna niekiedy ingerencja konserwatorska. Według Gwidona Chmarzyńskiego toruński mistrz miał wykonać cykl sześciu obrazów ze scenami z Nowego Testamentu oraz ich starotestamentowych prefiguracji na emporze kościoła w Gór$\mathrm{sku}^{72}$. Malowidła te prezentują jednak wyższy poziom artystyczny niż dekoracja stropu - wykonane zostały przez malarza lepszej klasy. Nie można przy tym zupełnie wykluczyć autorstwa Tiedemana, hipotetycznie mogły to być prace w większym stopniu wykonane przez niego oso-

${ }^{67}$ Ibid., s. 187-190, 201, 202.

${ }^{68}$ Ibid., s. 202.

${ }^{69}$ APT, EGWN, sygn. 77, s. 522.

${ }^{70}$ Ibid., s. 524.

${ }^{71}$ B. Schmid, Die Denkmalpflege in der Provinz Westpreussen im Jahre 1911, Danzig 1912, s. 22; Katalog zabytków sztuki w Polsce, t. XI: Województwo bydgoskie, z. 16: Powiat toruński, oprac. T. Chrzanowski, M. Kornecki, Warszawa 1972, s. 33.

${ }^{72}$ G. Chmarzyński, Sztuka w Toruniu. Zarys dziejów, [w:] Dzieje Torunia, red. K. Tymieniecki, Torun 1933, s. 540-541. Teza ta przyjęta została przez późniejszych badaczy: P. Birecki, Sztuka luterańska na ziemi chelmińskiej od drugiej połowy XVI do pierwszej ćwierci XVIII wieku, Warszawa 2007, s. 248, 272-280. 


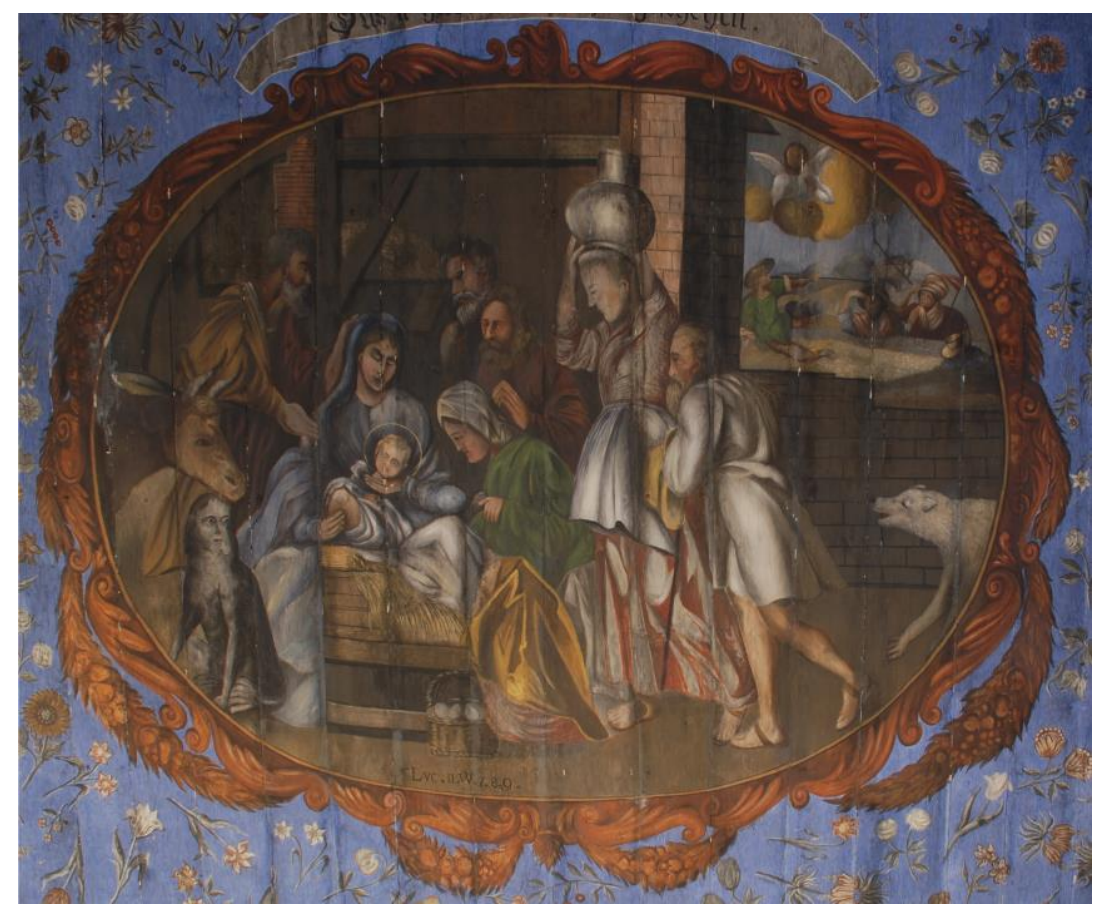

Il. 8. Warsztat Johanna Tiedemana starszego, Pokłon pasterzy, fragment dekoracji stropu kościoła w Górsku, 1694. Fot. B. Łyczak

biście. Często wiązana z omawianym mistrzem była także dekoracja empory organowej w kościele w Rogowie, o programie ikonograficznym podobnym do chóru w Górsku ${ }^{73}$. Nosi ona jednak sygnaturę Davida Heydemana, innego miejscowego malarza, członka toruńskiego cechu ${ }^{74}$. $\mathrm{Z}$ tego powodu odrzucić trzeba także autorstwo Tiedemana w przypadku dzieł przypisanych mu na zasadzie wielopiętrowej hipotezy: dekoracji

${ }^{73}$ K. Kluczwajd, J. Tylicki, Sztuka nowożytna, s. 280; J. Tylicki, Sztuka Prus Królewskich. Malarstwo i rysunek, [w:] Prusy Królewskie. Spoleczeństwo, kultura, gospodarka 1454-1772, red. E. Kizik, Gdańsk 2012, s. 341.

${ }^{74}$ P. Birecki, Sztuka luterańska, s. 249 (tu błędnie odczytany podpis: Heldssman). Na temat malarza por.: B. Dybaś, Heydeman David, SAP, Uzupełnienia i sprostowania do t. 3, Warszawa 1993, s. 7. 
na stallach połączonych z konfesjonałami w kościele w Świerczynkach oraz malowideł krajobrazowych na ambonie w Rogowie ${ }^{75}$. Polichromię przedstawiającą Pokłon pasterzy umieszczoną w 1702 r. na stropie nad ołtarzem w rogowskiej świątyni, powiązaną z Tiedemanem przez Piotra Bireckiego, również uznać należy za dzieło Davida Heydema$\mathrm{na}^{76}$. Johannowi Tiedemanowi starszemu bywał atrybuowany także obraz epitafijny Ursuli Trautwein, z domu Gernerin, ze sceną Zmartwychwstanie Chrystusa z kościoła Najświętszej Marii Panny w Toruniu, opatrzony datą $1676^{77}$. Malowidło zdradza co prawda pewne podobieństwa formalne do dekoracji empory muzycznej w Górsku, prezentuje jednak wyższą klasę artystyczną. Według sugestii Jacka Tylickiego, dzieło powstało około połowy XVII w., a inskrypcja $\mathrm{z}$ datą dodana została później ${ }^{78}$.

Johann (III) Tiedeman - zwany w literaturze przedmiotu „młodszym" - ochrzczony został 31 VII 1669 r. ${ }^{79}$ Dnia 17 III 1680 r., a więc w wieku 11 lat, przyjęto go do Toruńskiego Gimnazjum Akademickie$\mathrm{go}^{80}$. Zapewne wcześniej uczęszczał do szkoły nowomiejskiej, kształcącej na poziomie najniższych klas. Po czteroletniej edukacji w Gimnazjum, 3 VII $1684 \mathrm{r}$. Johann (III) rozpoczął naukę malarstwa w warsztacie swojego ojca ${ }^{81}$. Termin ukończył w roku $1689^{82}$, a na temat na-

\footnotetext{
${ }^{75}$ K. Kluczwajd, J. Tylicki, Sztuka nowożytna, s. 280, 281; J. Tylicki, Sztuka Prus Królewskich, s. 341.

${ }^{76} \mathrm{~W}$ innym miejscu badacz ten zasugerował, że autorem malowidła w Rogowie mógł być Daniel Tiedeman - P. Birecki, Sztuka luterańska, s. 249, 271.

${ }_{77}$ Z. Kruszelnicki, Obraz „Adoracja Baranka Apokaliptycznego” z dawnego kościota Św. Trójcy w Toruniu, [w:] Ars una. Prace z historii sztuki, red. E. Iwanoyko, Poznań 1976, s. 117; Dzieje sztuki Torunia, il. 202.

${ }^{78}$ K. Kluczwajd, J. Tylicki, Sztuka nowożytna, s. 237, 238; J. Tylicki, Sztuka Prus Królewskich, s. 338, 339. Badacz hipotetycznie połączył obraz z Samuelem Hyppericusem, toruńskim malarzem działającym poza systemem cechowym, nie są jednak znane jakiekolwiek pewne dzieła tego twórcy. Warto dodać, że Peter Trautwein, mąż Ursuli, 9 VII 1675 r. zapłacił 20 zł za nagrobek na toruńskim cmentarzu św. Jerzego, w kaplicy należącej do wdowy po Michaelu Wincklerze, gdzie miał być pochowany wraz z żoną - APT, EGWJ, sygn. 132, s. 84.

${ }^{79}$ AADDT, NMP, sygn. AA001, s. 363.

${ }^{80}$ MUTGA, nr 6843.

${ }^{81}$ APT, Cech malarzy, sygn. 4, s. 157.

${ }^{82}$ Ibid., s. 163.
} 
stępnych kilku lat jego życia - w tym trasy wędrówki czeladniczej nie udało się dotąd odnaleźć żadnych informacji. W toruńskiej organizacji rzemieślniczej Tiedeman młodszy zameldował się $11 \mathrm{~V} 1694 \mathrm{r}^{83}$ Ponieważ był synem mistrzowskim, zgodnie ze statutem organizacji przysługiwało mu zwolnienie $\mathrm{z}$ obowiązku przepracowania próbnego roku $\left(\right.$ Mutjahr) ${ }^{84}$. W związku z tym już 6 VI 1694 r. zlecono mu w ramach majstersztyku wykonanie dwóch scen religijnych, sprawdzających umiejętności posługiwania się różnymi technikami malarskimi: Nakarmienie 9000 - farbami olejnymi oraz Walkę św. Michata Archanioła ze smokiem - temperami ${ }^{85} .26$ października tego roku Tiedeman uzyskał status mistrza i tego samego dnia przydzielono do jego warsztatu Davida Heydemana, który rozpoczął wówczas swój Mutjahr ${ }^{86}$. Obywatelstwo Torunia malarz otrzymał w roku $1695^{87}$. Mieszkał w domku położonym nad Wisłą, przy Bramie Mostowej, poza murami miejskimi, gdzie został odnotowany w latach 1709-1714.

Jeszcze w 1695 r. malarz ożenił się z nieznaną z nazwiska Anną Marią. Para miała przynajmniej czworo dzieci, z których troje zmarło w wieku niemowlęcym: Christina (chrz. 14 IV 1696; poch. 16 II 1698 ${ }^{88}$ ), Samuel (chrz. 3 IX 1697; poch. 18 II 1698 ${ }^{89}$ ) i Georg (chrz. 13 VIII 1702; poch. 28 IX $1702^{90}$ ). Losy jednego z dzieci - Johanna Gottlieba (chrz. 15 XII $1699^{91}$ ) nie są znane.

\footnotetext{
${ }^{83}$ Ibid., s. 170.

${ }^{84}$ Statut cechu malarzy, s. 113, par. 14.

${ }^{85}$ APT, Cech malarzy, sygn. 4, s. 172.
}

${ }^{86}$ Ibid., s. 173, 174. David Heydeman odbył tylko połowę nakazanego przez statut roku próby, z drugiej jego części się wykupił - B. Dybaś, Heydeman David, s. 7. Piotr Birecki nieprawidłowo interpretując zapis w księdze protokołów cechu malarskiego uznał, że D. Heydeman i J. Tiedeman podjęli wówczas współpracę „przy wykonywaniu bliżej nieokreślonych prac malarskich”, które utożsamił z dekoracją stropu i empory w Górsku - P. Birecki, Sztuka luterańska, s. 249, 273-274.

${ }^{87}$ A. Semrau, Die Bürgerlisten, T. 1: Die einheimischen Bürger, Mitteilungen des Coppernicus-Vereins für Wissenschaft und Kunst zu Thorn, H. 27: 1919, s. 75.
${ }^{88}$ AADDT, NMP, sygn. AA002, s. 90; APT, EGWJ, sygn. 132, s. 250.
${ }^{89}$ AADDT, NMP, sygn. AA002, s. 98; APT, EGWJ, sygn. 132, s. 250.
${ }^{90}$ AADDT, NMP, sygn. AA002, s. 130; APT, EGWJ, sygn. 132, s. 279.
${ }^{91}$ AADDT, NMP, sygn. AA002, s. 111. 
Tabela 3a. Chrzty, przy których świadkiem był Johann (III) Tiedeman (młodszy)

\begin{tabular}{|c|c|c|c|c|c|}
\hline Data & $\begin{array}{c}\text { Imię } \\
\text { dziecka }\end{array}$ & Ojciec & $\begin{array}{c}\text { Zawód } \\
\text { ojca }\end{array}$ & Matka & Źródło \\
\hline 1 & 2 & 3 & 4 & 5 & 6 \\
\hline $24 \mathrm{~V} 1702$ & Eva & $\begin{array}{l}\text { Casper } \\
\text { Kantzler }\end{array}$ & ogrodnik & $\begin{array}{c}\text { Anna Maria } \\
\text { Hecke }\end{array}$ & $\begin{array}{c}\text { APT, EGWN, } \\
\text { sygn. } 78, \\
\text { s. } 18 \\
\end{array}$ \\
\hline 23 VII 1702 & Jacob & $\begin{array}{c}\text { Daniel } \\
\text { Tiedeman }\end{array}$ & malarz & $\begin{array}{l}\text { Elisabeth } \\
\text { Seidler }\end{array}$ & $\begin{array}{c}\text { AADDT, NMP, } \\
\text { sygn. AA002, } \\
\text { s. } 130 \\
\end{array}$ \\
\hline 25 IX 1703 & Anna & $\begin{array}{l}\text { Casper } \\
\text { Kantzler }\end{array}$ & ogrodnik & $\begin{array}{c}\text { Anna Maria } \\
\text { Hecke }\end{array}$ & $\begin{array}{c}\text { APT, EGWN, } \\
\text { sygn. } 78, \\
\text { s. } 29 \\
\end{array}$ \\
\hline 11 I 1705 & Daniel & Peter Ritmer & żołnierz & Anna Brißen & $\begin{array}{c}\text { APT, EGWN, } \\
\text { sygn. } 78, \\
\text { s. } 37 \\
\end{array}$ \\
\hline 27 VIII 1705 & Gottfried & Simon Barck & snycerz & $\begin{array}{l}\text { Elisabeth } \\
\text { Tiedeman }\end{array}$ & $\begin{array}{c}\text { AADDT, NMP, } \\
\text { sygn. AA002, } \\
\text { s. } 149 \\
\end{array}$ \\
\hline 14 II 1706 & Friedrich & Jacob Lentz & wieś & Elisabeth & $\begin{array}{l}\text { APT, EGWN } \\
\text { sygn. } 78, \\
\text { s. } 46 \\
\end{array}$ \\
\hline 31 VII 1707 & $\begin{array}{c}\text { Anna } \\
\text { Elisabeth }\end{array}$ & $\begin{array}{c}\text { Martin } \\
\text { Reinhold }\end{array}$ & wieś & Anna Foß & $\begin{array}{c}\text { AADDT, NMP, } \\
\text { sygn. AA002, } \\
\text { s. } 160 \\
\end{array}$ \\
\hline 30 IX 1707 & Anna & Johann Beck & gwoździarz & Maria Hese & $\begin{array}{l}\text { APT, EGWN, } \\
\text { sygn. } 78, \\
\text { s. } 60 \\
\end{array}$ \\
\hline 26 II 1708 & Marianna & $\begin{array}{l}\text { Wojciech } \\
\text { Dreliński }\end{array}$ & plebs & Katarzyna & $\begin{array}{l}\text { AADDT, Jan, } \\
\text { sygn. AA004, } \\
\text { s. } 222 \\
\end{array}$ \\
\hline 5 III 1708 & Marianna & $\begin{array}{c}\text { Andrzej } \\
\text { Chełmoński }\end{array}$ & plebs & Agnieszka & $\begin{array}{l}\text { AADDT, Jan, } \\
\text { sygn. AA004, } \\
\text { s. } 223 \\
\end{array}$ \\
\hline 29 VIII 1709 & Gottfried & $\begin{array}{c}\text { Christian } \\
\text { Stahn }\end{array}$ & postrzygacz & $\begin{array}{c}\text { Maria } \\
\text { Tiedeman }\end{array}$ & $\begin{array}{c}\text { APT, EGWN, } \\
\text { sygn. } 78, \\
\text { s. } 78 \\
\end{array}$ \\
\hline 13 III 1710 & Barbara & $\begin{array}{l}\text { Friedrich } \\
\text { Heger }\end{array}$ & żołnierz & Anna Reichel & \begin{tabular}{|c|} 
APT, EGWN, \\
sygn. 78, \\
s. 84 \\
\end{tabular} \\
\hline 23 III 1712 & Maria & Peter Krahn & wieś & $\begin{array}{l}\text { Catharina } \\
\text { Scherer }\end{array}$ & $\begin{array}{c}\text { AADDT, NMP, } \\
\text { sygn. AA002, } \\
\text { s. } 193 \\
\end{array}$ \\
\hline
\end{tabular}




\begin{tabular}{|c|c|c|c|c|c|}
\hline 1 & 2 & 3 & 4 & 5 & 6 \\
\hline 20 I 1715 & Sebastian & $\begin{array}{c}\text { Fabian } \\
\text { Wyrwicki }\end{array}$ & zakrystianin & Małgorzata & $\begin{array}{c}\text { AADDT, Jakub, } \\
\text { sygn. AA001, } \\
\text { s. 301 }\end{array}$ \\
\hline 5 I 1716 & Christina & Jacob Heyer & wieś & Maria Groß & $\begin{array}{c}\text { AADDT, NMP, } \\
\text { sygn. AA002, } \\
\text { s. 221 }\end{array}$ \\
\hline 19 XII 1717 & Christian & $\begin{array}{c}\text { Heinrich } \\
\text { Weiß }\end{array}$ & piekarz & $\begin{array}{c}\text { Anna Maria } \\
\text { Morche }\end{array}$ & $\begin{array}{c}\text { APT, EGWN, } \\
\text { sygn. 78, } \\
\text { s. 163 }\end{array}$ \\
\hline
\end{tabular}

Tabela 3b. Chrzty, przy których świadkiem była Anna Maria Tiedeman

\begin{tabular}{|c|c|c|c|c|c|}
\hline Data & $\begin{array}{c}\text { Imię } \\
\text { dziecka }\end{array}$ & Ojciec & $\begin{array}{c}\text { Zawód } \\
\text { ojca }\end{array}$ & Matka & Źródło \\
\hline 3 II 1697 & Constantia & $\begin{array}{c}\text { Ephraim } \\
\text { Koch }\end{array}$ & drukarz & $\begin{array}{c}\text { Constantia } \\
\text { Remling }\end{array}$ & $\begin{array}{c}\text { AADDT, NMP, } \\
\text { sygn. AA002, } \\
\text { s. 94 }\end{array}$ \\
\hline 16 III 1706 & Anna Maria & $\begin{array}{c}\text { Christian } \\
\text { Stahn }\end{array}$ & postrzygacz & $\begin{array}{c}\text { Maria } \\
\text { Tiedeman }\end{array}$ & $\begin{array}{c}\text { APT, EGWN, } \\
\text { sygn. 78, } \\
\text { s. 47 }\end{array}$ \\
\hline 14 IV 1706 & Elisabeth & $\begin{array}{c}\text { Matthias } \\
\text { Kowalski }\end{array}$ & plebs & Maria & $\begin{array}{c}\text { APT, EGWJ, } \\
\text { sygn. 67, } \\
\text { s. 180 }\end{array}$ \\
\hline 13 XI 1706 & Catharina & Martin Bosch & wieś & N & $\begin{array}{c}\text { AADDT, NMP, } \\
\text { sygn. AA002, } \\
\text { s. 157 }\end{array}$ \\
\hline 6 III 1709 & Anna Maria & $\begin{array}{c}\text { Michael } \\
\text { Rüdiger }\end{array}$ & żołnierz & $\begin{array}{c}\text { Elisabeth } \\
\text { Rettel }\end{array}$ & $\begin{array}{c}\text { APT, EGWN, } \\
\text { sygn. 78, } \\
\text { s. 73 }\end{array}$ \\
\hline 14 IV 1709 & Euphrosina & $\begin{array}{c}\text { Michael } \\
\text { Müller }\end{array}$ & wieś & Maria Göde & $\begin{array}{c}\text { AADDT, NMP, } \\
\text { sygn. AA002, } \\
\text { s. 172 }\end{array}$ \\
\hline 19 VII 1709 & Anna Maria & Michael Miltz & wieś & N & $\begin{array}{c}\text { AADDT, NMP, } \\
\text { sygn. AA002, } \\
\text { s. 173 }\end{array}$ \\
\hline 3 IV 1711 & Ignacy & $\begin{array}{c}\text { Marcin } \\
\text { Miłkiewicz }\end{array}$ & plebs & Barbara & $\begin{array}{c}\text { AADDT, Jan, } \\
\text { sygn. AA004, } \\
\text { s. 254 }\end{array}$ \\
\hline 17 IX 1717 & Dorothea & $\begin{array}{c}\text { Johann Chri- } \\
\text { stian Neuman }\end{array}$ & młynarz & Catharina \\
Hase & $\begin{array}{c}\text { APT, EGWN, } \\
\text { sygn. 78, } \\
\text { s. 159 }\end{array}$ \\
\hline Elisabeth & Gottfried Fritz & kowal & $\begin{array}{c}\text { Elisabeth } \\
\text { Schmidt }\end{array}$ & $\begin{array}{c}\text { AADDT, NMP, } \\
\text { sygn. AA002, } \\
\text { s. 178 }\end{array}$ \\
\hline
\end{tabular}


Johann (III) i Anna Maria Tiedemanowie byli bardziej popularni niż jego rodzice oraz dziadkowie wśród współmieszkańców Torunia i okolic. Świadkowali w sumie przy 26 chrztach. Czterokrotnie trzymali do chrztu dzieci rodzeństwa Johanna, pięć razy potomstwo przedstawicieli rzemiosł i średniozamożnego pospólstwa, dziesięcioro dzieci wywodzących się z plebsu oraz siedmioro ze wsi położonych po lewej stronie Wisły.

Tabela 4. Świadkowie chrztów dzieci Johanna (III) Tiedemana (młodszego)

\begin{tabular}{|c|c|c|c|c|}
\hline $\begin{array}{c}\text { Imię } \\
\text { dziecka }\end{array}$ & Data & Świadek & Zawód & Źródło \\
\hline Christina & 15 IV 1696 & Nathanael Köhler & kupiec & $\begin{array}{c}\text { NMP, } \\
\text { sygn. AA002, } \\
\text { s. } 90\end{array}$ \\
\hline Christina & 15 IV 1696 & $\begin{array}{l}\text { Justina Elisabeth } \\
\text { Dzikowska }\end{array}$ & żona pastora & ibid. \\
\hline Christina & 15 IV 1696 & Anna Steiner & żona kuśnierza & ibid. \\
\hline Samuel & 3 IX 1697 & Andreas Schultz & kopyciarz & $\begin{array}{c}\text { NMP, } \\
\text { sygn. AA002, } \\
\text { s. } 98 \\
\end{array}$ \\
\hline Samuel & 3 IX 1697 & Michael Siber & farbiarz & ibid. \\
\hline Samuel & 3 IX 1697 & Benigna Herede & żona lekarza & ibid. \\
\hline $\begin{array}{c}\text { Johann } \\
\text { Gottlieb }\end{array}$ & 15 XII 1699 & Heinrich Prochnau & kupiec & $\begin{array}{c}\text { NMP, } \\
\text { sygn. AA002, } \\
\text { s. } 111 \\
\end{array}$ \\
\hline $\begin{array}{l}\text { Johann } \\
\text { Gottlieb }\end{array}$ & 15 XII 1699 & Abraham Arendt & kupiec & ibid. \\
\hline $\begin{array}{c}\text { Johann } \\
\text { Gottlieb } \\
\end{array}$ & 15 XII 1699 & $\begin{array}{c}\text { Anna Catharina } \\
\text { Rößner } \\
\end{array}$ & żona uczonego & ibid. \\
\hline Georg & 13 VIII 1702 & Georg Meißner & uczony & $\begin{array}{c}\text { NMP, } \\
\text { sygn. AA002, } \\
\text { s. } 130 \\
\end{array}$ \\
\hline Georg & 13 VIII 1702 & Johann Zernecke & kupiec & ibid. \\
\hline Georg & 13 VIII 1702 & $\begin{array}{l}\text { Concordia } \\
\text { Zernecke }\end{array}$ & żona uczonego & ibid. \\
\hline
\end{tabular}

Bardzo ważny - w kontekście działalności artystycznej - wydaje się dobór chrzestnych dla potomstwa Tiedemanów. Przy ich chrztach świadkowało dziewięciu przedstawicieli elity miejskiej i dwóch boga- 
tego pospólstwa. Najciekawiej wyglądał wybór chrzestnych dla najmłodszego z dzieci Johanna (III) - Georga. Dnia 13 VIII 1702 r. (!) przy jego chrzcie świadkami byli Georg Meißner, uczony, oraz kupiec Johann Zernecke i jego synowa Concordia Zernecke. Dwoje z nich to ojciec (a zarazem inwestor) oraz żona właściciela kamienicy przy ul. Żeglarskiej 16 i zleceniodawcy wykonania w niej malowideł stropowych - Jacoba Heinricha Zerneckego. Data chrztu oraz osoby świadków zdają się wskazywać na dokładny czas wykonania prac dekoracyjnych w kamienicy przez Johanna Tiedemana młodszego.

Obecnie nie są zidentyfikowane żadne zachowane dzieła mistrza. Wiadomo jedynie, że w latach 1705-1707 pracował wraz z bratem Danielem przy ponownym wystroju i wyposażeniu toruńskiego, przedmiejskiego kościoła pw. św. Jerzego, zniszczonego podczas oblężenia szwedzkiego w 1703 r. Według księgi rachunkowej świątyni w 1706 r. odnowił na własny koszt ołtarz. W tym samym roku otrzymał $84 \mathrm{zł}$ za niesprecyzowane roboty, prawdopodobnie była to pierwsza rata za dekorację chóru muzycznego, za którą wkrótce „malarz Tiedeman” zatem Johann młodszy lub Daniel, a być może obaj współpracujący przy dużym zleceniu - otrzymał $105 \mathrm{zl}^{92}$. Nie sprecyzowano również, któremu z braci zapłacono za pozłocenie kuli i krzyża wieńczących szczyt prezbiterium (26 VIII 1705, $30 \mathrm{zl}$ ) oraz kuli i chorągiewki na wieży (31 X 1705, 39 zł), wykonanie obrazów zdobiących szczyt kościoła, a także za naprawę obrazu Złożenie do grobu (1707, 6 zł) oraz oczyszczenie i pomalowanie ram $(1707,6 \mathrm{zl})^{93}$. Mistrz podejmował się także zleceń w domach prywatnych: zachował się rachunek za odnowienie ścian $\mathrm{w}$ dwóch pokojach $\mathrm{w}$ domu Zimmermanna i zamocowanie na nich płócien, opatrzony datą 14 XII 1715 r. ${ }^{94}$ Prace te, wycenione na 6 zł 21 gr, opłaciła toruńska kamlaria; zleceniodawca dostarczył także farby.

Nie jest zatem znane żadne pewne dzieło autorstwa Johanna Tiedemana młodszego, z którym zestawić można malowidła w kamienicy Zerneckego. Jako pośredni materiał porównawczy posłużyć może je-

\footnotetext{
${ }^{92}$ APT, EGWJ, sygn. 132, s. 357, 358.

${ }^{93}$ Ibid., s. 328, 330, 333, 368.

${ }^{94}$ APT, Akta miasta Torunia (dalej cyt. AmT), kat. II, Akta luźne, sygn. 9391: Rachunki malarzy i rzeźbiarzy z lat 1704-1768, s. 9.
} 
dynie dekoracja stropu w kościele w Górsku, wykonana przez warsztat prowadzony przez Johanna Tiedemana starszego. Malowidła te prezentują niezbyt wysoką klasę artystyczną, duży udział w ich wykonaniu należy, jak się wydaje, przypisać pracownikom warsztatowym. Wiadomo, że u swojego ojca - a zarazem nauczyciela - służył wówczas jako czeladnik Daniel Tiedeman, a być może także bardziej już doświadczony Johann młodszy. Zarówno malowidło w Górsku, jak i dekoracja w kamienicy Zerneckego charakteryzują się linearnym sposobem kształtowania sylwetek ludzkich oraz ich szat, obwiedzionych wyraźnym konturem. Podobna jest także paleta barwna, $\mathrm{z}$ dominacją stonowanych kolorów ziemistych przełamanych błękitem i czerwienią. Rzuca się w oczy także predylekcja do szczegółowego oddawania modnych wówczas motywów kwiatowych i owocowych, wypełniających tło dla medalionów ze scenami figuralnymi w Górsku oraz kosze unoszone przez aniołki i festony po bokach sceny głównej w Toruniu ${ }^{95}$.

Do swojego warsztatu Johann Tiedeman młodszy przyjął czterech uczniów, przy czym jedynym, który ukończył naukę, był Heinrich Dure, przebywający na terminie od 30 IV 1696 r. do 21 II $1701 \mathrm{r}^{96} \mathrm{~W}$ przypadku pozostałych trzech: Christiana Letznera (zapisany 30 III 1701 na osiem lat), Carla Ernsta Bernandi (zapisany 5 V 1707 na pięć lat liczonych od św. Michała 1706) oraz Pettera Knutta (zapisany 26 IX 1710 na sześć lat liczonych od św. Jana tego roku) - brak informacji na temat wyzwolin ${ }^{97}$. W omawianej pracowni zatrudniony był też okresowo jako czeladnik Simon Schumacher, który 23 VI 1698 r. został ukarany przez cech kwotą 6 zł za niesprecyzowane wykroczenie ${ }^{98}$. Nadmieniono przy tym, że gdyby Tiedeman chciał w przyszłości korzystać z jego usług, również musiałby uiścić 6 zł. Malarz uregulował ponadto opłatę wynoszącą 9 zł, którą 20 VII 1699 r. nałożono na ucznia

\footnotetext{
${ }^{95}$ Dekoracja malarska w postaci rozrzuconych kwiatów znajdowała się także na stropie w kościele Trójcy Świętej w Toruniu, ozdobionym w 1679 r. - P. Birecki, Sztuka luterańska, s. 271; por. też rysunek Georga Friedricha Steinera: Toruń i miasta Ziemi Chetmińskiej na rysunkach Jerzego Fryderyka Steinera z pierwszej połowy XVIII wieku (tzw. Album Steinera), red. M. Biskup, Toruń 1998, s. 95, il. 47.

${ }^{96}$ APT, Cech malarzy, sygn. 4, s. 181, 196; B. Dybaś, Duve Heinrich, SAP, Uzupełnienia i sprostowania do t. 2, Warszawa 1993, s. 6.

${ }^{97}$ APT, Cech malarzy, sygn. 4, s. 197, 205, 210, 211.

${ }^{98}$ Ibid., s. 187.
} 
malarskiego Benjamina Spona, dwa tygodnie wcześniej zwolnionego z nauki w warsztacie Heinricha Christiana Sernera, natomiast 28 VIII 1702 r. zobowiązał się zapłacić karę za czeladnika Daniela Ortmanna ${ }^{99}$.

Mistrz okresowo miewał długi w cechu: spłata taksy majstrowskiej zajęła mu cały rok, a w późniejszym czasie - zwłaszcza w latach 16981699 i 1706 - zalegał ze składkami kwartalnymi, jednak ostatecznie je regulował ${ }^{100}$. Mimo to nie należał wówczas do rzemieślników ubogich, o czym świadczy wysokość opłaty pogłównego na poczet wojska wojewody kijowskiego w 1706 r., naliczanej proporcjonalnie do posiadanego majątku. Tiedeman uiścił wówczas 40 zł - najwięcej spośród toruńskich malarzy ${ }^{101}$. Hipotetycznie w późniejszych latach poziom jego zamożności uległ pogorszeniu, co ostatecznie skłoniło go do opuszczenia miasta. Ostatnia wzmianka na temat mistrza w aktach organizacji malarsko-rzeźbiarskiej odnosi się do 26 IX 1710 r. ${ }^{102} \mathrm{~W}$ następnych latach nadal funkcjonował w Toruniu, kilkakrotnie wystąpił jako świadek przy chrztach. Być może w 1717 lub 1718 r. wyjechał z Torunia i zapewne zmarł poza miastem. Co ciekawe, zachował się list polecający dla Tiedemana zaadresowany do Rady Miasta Torunia, a wysłany 30 VIII 1718 r. z Grudziądza przez kanclerza wielkiego koronnego Jana Szembeka ${ }^{103}$. Malarz, określony mianem ,sławetnego [...] mistrza sztuki malarskiej”, miał się wówczas znajdować w bardzo złym stanie finansowym.

Daniel Tiedeman, ochrzczony 2 IV 1674 r., został zapisany do Toruńskiego Gimnazjum wraz ze starszym bratem ${ }^{104}$. Następnie odbył naukę zawodu w pracowni Johanna Tiedemana starszego: rozpoczął termin 17 XI 1689 r., a zakończył go 11 V 1694 r. i od razu zatrudniony

${ }^{99}$ Ibid., s. 189, 200. D. Ortmann został później mistrzem w toruńskim cechu B. Łyczak, Funkcjonowanie cechowych warsztatów malarskich $w$ osiemnastowiecznym Toruniu na przyktadzie pracowni Daniela Ortmanna, [w:] Stare i nowe dziedzictwo Torunia, red. J. Raczkowski, Toruń 2013, s. 236-252.

${ }^{100}$ APT, Cech malarzy, sygn. 4, s. 173, 174, 178, 185, 187, 188, 202, 203.

${ }^{101}$ APT, AmT, kat. II, Akta luźne, sygn. 7224: Rejestr płatników kontrybucji wojennych pobranych od mieszczan toruńskich w 1706 r., s. 53.

${ }^{102}$ APT, Cech malarzy, sygn. 4, s. 210, 211.

${ }^{103}$ APT, AmT, kat. II, sygn. I-3303, s. 827; P. Birecki, Sztuka luterańska, s. 273.

${ }^{104}$ MUTGA, nr 6845. Na temat D. Tiedemana por.: B. Łyczak, Tiedemann Daniel, TSB, t. 7, Toruń 2014, s. 229-230. 
został przez ojca jako czeladnik ${ }^{105}$. W tym czasie mistrz ten pracował nad dekoracją stropu w kościele w Górsku, zatem wielce prawdopodobny jest udział Daniela w powstaniu malowideł. Przebieg kariery czeladniczej młodego malarza oraz trasa jego wędrówki nie są znane. Do toruńskiego cechu zgłosił się 1 XI $1700 \mathrm{r}$. z zamiarem otrzymania uprawnień mistrzowskich ${ }^{106}$. W ramach majstersztyku zadano mu wykonanie Historii trzech króli farbami olejnymi oraz Narodzin Chrystusa temperami. Gotowe dzieła przedstawił 26 grudnia tego roku i został wówczas przyjęty do cechu, przy czym opłatę mistrzowską w wysokości 15 zł spłacał w ratach ${ }^{107}$. W roku 1701 uzyskał obywatelstwo Torunia ${ }^{108}$.

Daniel ożenił się 31 I 1701 r. z Elisabeth, córką piwowara Christopha Seidlera ${ }^{109}$. Mieli oni tylko jednego syna, Jacoba, ochrzczonego 23 VII 1702 r. $^{110}$, który najprawdopodobniej zmarł w dzieciństwie. Jego chrzestnymi byli: Johann (III) Tiedeman, powroźnik Gottfried Behnisch oraz Magdalena Schöning, żona kupca. Elisabeth Tiedeman zmarła w 1720 r.; pochowano ją 15 czerwca tego roku ${ }^{111}$.

Tabela 5a. Chrzty, przy których świadkiem był Daniel Tiedeman

\begin{tabular}{|c|c|c|c|c|c|c|c|}
\hline Data & $\begin{array}{c}\text { Nazwisko } \\
\text { dziecka }\end{array}$ & $\begin{array}{c}\text { Imię } \\
\text { dziecka }\end{array}$ & Imię ojca & $\begin{array}{c}\text { Zawód } \\
\text { ojca }\end{array}$ & $\begin{array}{c}\text { Nazwisko } \\
\text { matki }\end{array}$ & Imię matki & Źródło \\
\hline 1 & 2 & 3 & 4 & 5 & 6 & 7 & 8 \\
\hline $\begin{array}{c}12 \\
\text { XII } \\
1704\end{array}$ & Roletek & Tomasz & Jakub & plebs & $\mathrm{N}$ & Helena & $\begin{array}{c}\text { AADDT, Jan, } \\
\text { sygn. AA004, } \\
\text { s. 170 }\end{array}$ \\
\hline $\begin{array}{c}5 \\
\text { VII } \\
1705\end{array}$ & $\begin{array}{c}\text { Borkie- } \\
\text { wicz }\end{array}$ & Anna & Błażej & plebs & $\mathrm{N}$ & Elżbieta & $\begin{array}{c}\text { AADDT, Jan, } \\
\text { sygn. AA004, } \\
\text { s. 181 }\end{array}$ \\
\hline $\begin{array}{c}11 \\
\text { III } \\
1707\end{array}$ & $\begin{array}{c}\text { Pełdzi- } \\
\text { kowski }\end{array}$ & Marianna & Wojciech & plebs & $\mathrm{N}$ & Marianna & $\begin{array}{c}\text { AADDT, Jan, } \\
\text { sygn. AA004, } \\
\text { s. 209 }\end{array}$ \\
\hline
\end{tabular}

${ }^{105}$ APT, Cech malarzy, sygn. 4, s. 163, 171.

${ }^{106}$ Ibid., s. 194

${ }^{107}$ Ibid., s. 194, 195.

108 A. Semrau, Die Bürgerlisten, T. 1, s. 75.

${ }^{109}$ AADDT, NMP, sygn. AD001, s. 271

${ }^{110}$ Ibid., sygn. AA002, s. 130.

${ }^{111}$ APT, EGWJ, sygn. 132, s. 517. 


\begin{tabular}{|c|c|c|c|c|c|c|c|}
\hline 1 & 2 & 3 & 4 & 5 & 6 & 7 & 8 \\
\hline $\begin{array}{c}19 \\
X \\
1707\end{array}$ & Laskowski & Szymon & Mikołaj & plebs & $\begin{array}{l}\text { Borow- } \\
\text { czanka }\end{array}$ & Dorota & $\begin{array}{c}\text { AADDT, Jan, } \\
\text { sygn. AA004, } \\
\text { s. } 216\end{array}$ \\
\hline $\begin{array}{c}8 \\
\text { XII } \\
1707 \\
\end{array}$ & Stahn & $\begin{array}{l}\text { Christian } \\
\text { Gottlieb }\end{array}$ & Christian & postrzygacz & Tiedeman & Maria & \begin{tabular}{|c} 
APT, EGWN, \\
sygn. 78, \\
s. 61
\end{tabular} \\
\hline $\begin{array}{c}8 \\
\text { II } \\
1711\end{array}$ & Krahn & Elisabeth & Peter & wieś & Scherer & Catharina & \begin{tabular}{|c|} 
AADDT, \\
NMP, \\
sygn. AA002, \\
s. 185 \\
\end{tabular} \\
\hline $\begin{array}{c}15 \\
\text { III } \\
1711\end{array}$ & Kohl & Michael & Johann & żołnierz & Wicke & $\begin{array}{l}\text { Anna } \\
\text { Sophia }\end{array}$ & \begin{tabular}{|c} 
AADDT, \\
NMP, \\
sygn. AA002, \\
s. 185 \\
\end{tabular} \\
\hline $\begin{array}{c}21 \\
\text { VIII } \\
1711\end{array}$ & Rohn & Michael & Antonius & murarz & Neuman & Maria & \begin{tabular}{|c|} 
AADDT, \\
NMP, \\
sygn. AA002, \\
s. 188 \\
\end{tabular} \\
\hline $\begin{array}{c}24 \\
\text { I } \\
1713 \\
\end{array}$ & Plette & Jacob & $\begin{array}{l}\text { Christian } \\
\text { Heinrich }\end{array}$ & piekarz & Landsberg & Regina & $\begin{array}{c}\text { APT, EGWN, } \\
\text { sygn. } 78, \\
\text { s. } 109 \\
\end{array}$ \\
\hline $\begin{array}{c}19 \\
\text { VI } \\
1713 \\
\end{array}$ & Słowiński & Marianna & $\begin{array}{c}\text { Wawrzy- } \\
\text { niec }\end{array}$ & plebs & $\mathrm{N}$ & Katarzyna & $\begin{array}{c}\text { AADDT, Jan, } \\
\text { sygn. AA004, } \\
\text { s. } 276 \\
\end{array}$ \\
\hline \begin{tabular}{|c|}
14 \\
II \\
1714 \\
\end{tabular} & Kittelin & Daniel & Daniel & piekarz & Gröbner & Anna & \begin{tabular}{|c|} 
APT, EGWN, \\
sygn. 78, \\
s. 121
\end{tabular} \\
\hline $\begin{array}{c}22 \\
V \\
1714 \\
\end{array}$ & Kozłowski & Jan & Michał & plebs & $\mathrm{N}$ & Elżbieta & $\begin{array}{c}\text { AADDT, Jan, } \\
\text { sygn. AA004, } \\
\text { s. } 285 \\
\end{array}$ \\
\hline $\begin{array}{c}5 \\
\text { VIII } \\
1714 \\
\end{array}$ & Wyszyński & $\begin{array}{c}\text { Wawrzy- } \\
\text { niec }\end{array}$ & Michał & $\begin{array}{c}\text { przedmie- } \\
\text { stek }\end{array}$ & $\mathrm{N}$ & Cecylia & \begin{tabular}{|c} 
AADDT, Jan, \\
sygn. AA004, \\
s. 286 \\
\end{tabular} \\
\hline
\end{tabular}

Tabela 5b. Chrzty, przy których świadkiem była Elisabeth Tiedeman

\begin{tabular}{|c|c|c|c|c|c|c|c|}
\hline Data & $\begin{array}{c}\text { Nazwisko } \\
\text { dziecka }\end{array}$ & $\begin{array}{c}\text { Imię } \\
\text { dziecka }\end{array}$ & Imię ojca & $\begin{array}{c}\text { Zawód } \\
\text { ojca }\end{array}$ & $\begin{array}{c}\text { Nazwisko } \\
\text { matki }\end{array}$ & Imię matki & Źródło \\
\hline $\begin{array}{c}11 \\
\text { IX } \\
1706\end{array}$ & Riemer & Elisabeth & Ewald & wieś & $\mathrm{N}$ & Anna & $\begin{array}{c}\text { APT, EGWN, } \\
\text { sygn. 78, } \\
\text { s. 50 }\end{array}$ \\
\hline $\begin{array}{c}29 \\
\text { IV } \\
1708\end{array}$ & Barck & Daniel & Simon & snycerz & Tiedeman & Elisabeth & $\begin{array}{c}\text { AADDT, } \\
\text { NMP, } \\
\text { sygn. AA002, } \\
\text { s. 166 }\end{array}$ \\
\hline
\end{tabular}


Daniel wystąpił 13 razy jako świadek przy chrztach torunian. Wśród jego chrześniaków byli: siostrzeniec (syn postrzygacza sukna Christiana Stahna i siostry Marii), dwóch synów piekarzy, jeden - murarza i aż dziewięciu przedstawicieli plebsu (w tym siedmiu katolików). Jego żona świadkowała przy dwóch chrztach: siostrzeńca męża i dziecka gospodarza z pobliskiej wsi. Charakterystyczna jest obecność Daniela przy chrztach katolików. Musiał być w tej grupie popularny, może ze względu na prace malarskie wykonywane w którejś ze świątyń katolickich.

W latach 1709-1714 Daniel został odnotowany jako lokator w siedzibie kancelarii miejskiej (Rynek Staromiejski 6 [A] - dziś część Dworu Artusa ${ }^{112}$. Hipotetycznie podnajmował tam izbę u brata Michaela.

Malarz regularnie zalegał z terminowymi spłatami składek kwartalnych do kasy cechowej: po raz pierwszy 19 XI 1703 r., a następnie w latach 1706, 1710, 1712 i $1713^{113}$. Ponadto wiadomo, że 26 IX $1710 \mathrm{r}$. oddał 24 zł pożyczone od innego miejscowego mistrza, Daniela Ortmanna, i pozostawał dłużny jeszcze $6 \mathrm{zl}^{114}$. Dnia 19 II 1707 r. odbyło się zwołane na wniosek Tiedemana nadzwyczajne zebranie cechu, podczas którego zawarł on ugodę z czeladnikiem Lorentzem Rosenbachem, niestety szczegóły sprawy pozostają nieznane ${ }^{115}$. Do warsztatu mistrza przyjęty został na termin tylko jeden uczeń: Martin Eÿsenkraut, zapisany 3 VII 1712 r. na siedem lat liczonych od św. Michała 1711 r. ${ }^{116}$

Znane są informacje na temat prac realizowanych przez Tiedemana w Toruniu. W roku 1706 odnowił własnym sumptem ambonę w kościele św. Jerzego oraz wykonał kosztem 5 zł epitafium, które zawisło $\mathrm{w}$ tej świątyni nad fotelami rajców ${ }^{117}$. Prawdopodobnie uczestniczył też w innych pracach przy renowacji tego kościoła ${ }^{118}$. Dnia 18 II $1706 \mathrm{r}$. pobrał z kasy kamlarii 24 zł za wybudowanie z desek i pomalowanie

${ }^{112}$ APT, [Rolle], s. 10, 43, 78, 129, 170, 201.

113 APT, Cech malarzy, sygn. 4, s. 201, 203, 209, 212, 213.

${ }^{114}$ Ibid., s. 210.

115 Ibid., s. 205 .

${ }^{116}$ Ibid., s. 212.

${ }^{117}$ APT, EGWJ, sygn. 132, s. 358, 360; P. Birecki, Sztuka luterańska, s. 111, 349, 351. W tym samym roku czeladnik D. Tiedemana otrzymał z kasy kościelnej 1 zł 6 gr za niesprecyzowane prace - APT, EGWJ, sygn. 132, s. 359.

${ }^{118}$ Por. wyżej w tekście. 
repozytorium dla starszych Rady Miasta Torunia ${ }^{119}$. Inną pracą powierzoną mu przez władze była dekoracja domu w północno-wschodnim narożniku Rynku Staromiejskiego, przeznaczonego dla pastora Christopha Heinricha Andreasa Gereta. Mistrz otrzymał za nią $68 \mathrm{zł} \mathrm{w}$ dwóch ratach wypłacanych w dniach 3 XI i 15 XII 1714 r. ${ }^{120} \mathrm{~W}$ tym samym czasie na zlecenie rajców podjął się innej typowo rzemieślniczej roboty: pomalował na czarno i pozłocił kryty pojazd konny (Chai$s e)^{121}$. Piotr Birecki hipotetycznie połączył $\mathrm{z}$ warsztatem Tiedemana niezachowane i nieznane $\mathrm{z}$ żadnych przekazów ikonograficznych malowidła z postaciami 12 apostołów na chórze w kościele w Lubiczu, opłacone w lutym 1714 r., brak jednak na poparcie tej tezy jakichkolwiek przesłanek źródłowych ${ }^{122}$.

W 1716 r. Daniel Tiedeman opuścił Toruń z powodu złej sytuacji finansowej - był już nieobecny na zebraniu cechowym 28 stycznia i przez kolejne cztery lata działał poza miastem ${ }^{123}$. W tym czasie, 24 XI 1716 r., mistrzowie cechowi wyzwolili Martina Eÿsenkrauta, który oprócz zwyczajowej opłaty musiał także uregulować zaległe składki kwartalne za swojego nieobecnego mistrza ${ }^{124}$. Po wyjeździe z Torunia Tiedeman pracował na terenie Prus Górnych w Królestwie Prus. W 1716 r. namalował trzy nieistniejące dziś obrazy do ołtarza w kościele w Kisielicach: Ostatnia Wieczerzę, Ukrzyżowanie i Trójcę Świętą ${ }^{125}$.

${ }^{119}$ APT, AmT, kat. II, sygn. XVI-362: Księga kasowa kamlarii miasta Torunia 1705 1706, s. 167.

${ }^{120}$ APT, AmT, kat. II, sygn. XVI-371: Księga kasowa kamlarii miasta Torunia 17141715 , s. 128,129 .

${ }^{121}$ Zachował się rachunek rozliczony 15 XII 1714 r., opiewający na 27 zł: 18 zł za pomalowanie na czarno i pozłocenie powozu oraz 9 zł za namalowanie łabędziej szyi APT, AmT, kat. II, Akta luźne, sygn. 9391, s. 8. W księgach kasowych kamlarii zanotowano, że dekoracje powozu kosztowały 24 zł-APT, AmT, kat. II, sygn. XVI-371, s. 140.

${ }^{122}$ P. Birecki, Sztuka luterańska, s. 247.

${ }^{123}$ APT, AmT, kat. II, sygn. II-26: Rathsprotocolle 1722, k. 48, 48v; Cech malarzy, sygn. 4, s. 216.

${ }^{124}$ APT, Cech malarzy, sygn. 4, s. 216. M. Eÿsenkraut pracował przez następne lata w Toruniu jako czeladnik: dnia 3 X 1720 r. został ukarany kwotą 4 zł, którą spłacić miał w ciągu ośmiu dni (APT, Cech malarzy, sygn. 4, s. 218).

${ }^{125}$ B. Schmid, Die Denkmalpflege in der Provinz. Westpreussen im Jahre 1912, Danzig 1913, s. 12; P. Birecki, Sztuka luterańska, s. 111; K. Kluczwajd, J. Tylicki, Sztuka nowożytna, s. 282; J. Tylicki, Sztuka Prus Królewskich, s. 343. 
Z kolei w 1719 r. wykonał polichromię prospektu organowego w kościele w Prabutach, również niezachowanego ${ }^{126}$. Według inskrypcji na obudowie instrumentu koszt powstania dekoracji pokrył sam malarz w celu upamiętnienia Michaela Unrucha, ławnika w Prabutach oraz swojego dziadka ze strony matki.

W 1720 r. Daniel Tiedeman powrócił do Torunia, natomiast dwa lata później zgłosił chęć ponownego uzyskania obywatelstwa, utraconego w związku z wyjazdem z miasta. Sprawa ta po raz pierwszy stanęła na posiedzeniu rajców 30 stycznia: nakazano mu wówczas okazać dokumenty odnoszące się do jego działalności w okresie spędzonym poza Toruniem ${ }^{127}$. W kwietniu tego roku Tiedeman zaproponował, że w zamian za przyznanie mu obywatelstwa bez naliczania za to opłaty pomaluje wnętrze kościoła Najświętszej Marii Panny ${ }^{128}$. Członkowie Rady mieliby dostarczyć jedynie materiały: farby i oleje, a mistrz nie pobrałby wynagrodzenia za robociznę, które oszacował na ponad 50 talarów. Na posiedzeniu Rady Miasta 24 kwietnia zdecydowano się zlecić Tiedemanowi prace w kościele Mariackim, pod warunkiem, że koszt materiałów zamknie się w $120 \mathrm{zt}^{129}$. W imieniu cechu malarzy wystąpił wówczas Reinhold Theodor Schönwald, pełniący obowiązki patrona organizacji. Toruńscy mistrzowie wnioskowali o nieprzyznawanie Tiedemanowi obywatelstwa, dopóki nie dojdzie on do porozumienia $\mathrm{z}$ korporacją $\mathrm{w}$ sprawie jego wyjazdu bez powiadomienia i uregulowania składek kwartalnych oraz nie wytłumaczy się ze współpracy z partaczami. Dnia 15 maja postanowiono odrzucić wniosek malarza, zapewne o nadanie praw miejskich ${ }^{130}$. Mimo to ostatecznie pomalował on wnętrza kościoła Mariackiego, za co wypłacono mu z kasy miej-

${ }^{126}$ B. Schmid, Die Bau- und Kunstdenkmäler der Provinz Westpreussen, H. XII: Kreis Rosenberg, Danzig 1906, s. 187; W. Renkewitz, J. Janca, Geschichte der Orgelbaukunst in Ost- und Westpreussen von 1333 bis 1944, Bd. I, Würzburg 1984, s. 162, il. 61. Dekoracja malarska prospektu bywa niesłusznie datowana na 1707 r. - K. Kluczwajd, J. Tylicki, Sztuka nowożytna, s. 282.

${ }_{127}$ APT, AmT, kat. II, sygn. II-26, k. 48, 48v.

${ }^{128}$ Odpowiednie pismo wpłynęło do kancelarii miejskiej dnia 13 IV 1722 r. APT, AmT, kat. II, sygn. I-3401: „Briefe an den Rath. 7. Gesuche, Anträge etc. aus der Bürgerschaft. 1722-1724 incl.”, s. 81-84.

${ }^{129}$ APT, AmT, kat. II, sygn. II-26, k. 186v, 187r.

${ }^{130}$ Ibid., k. 219r, 219v. 
skiej $50 \mathrm{zf}^{131}$. Ponadto 3 lipca nakazano cechowi dopuścić Tiedemana na najbliższe zebranie oraz wysłuchać go ${ }^{132}$. Malarz zobowiązał się uregulować 6 zł kary względem organizacji i 29 IX 1722 r. uczestniczył w zebraniu na kwartał św. Michała ${ }^{133}$. Jest to zarazem ostatnia odnaleziona wzmianka na temat Daniela Tiedemana, który najprawdopodobniej opuścił Toruń i zmarł poza miastem.

$$
* * *
$$

Dla Michaela, swojego drugiego syna ochrzczonego 27 IX $1671 \mathrm{r}^{134}$, Johann (II) Tiedeman wybrał karierę inną niż malarza. Dnia 17 III 1680 r. - podobnie jak bracia - chłopiec rozpoczął naukę w gimnazjum w Toruniu $^{135}$. Po ukończeniu edukacji w tej szkole i krótkim pobycie na terminie w ojcowskim warsztacie (od 11 VII do 1 X $1691^{136}$ ) został w $1691 \mathrm{r}$. wysłany na studia do Królewca; jego wpis w metryce Albertiny oznaczony jest datą 18 października ${ }^{137}$. Nie wiadomo, jak długo studiował, raczej nie uzyskał magisterium. W 1697 r. lub nieco wcześniej osiadł w Brodnicy, gdzie został pisarzem ławy miejskiej (notarius scabinorum). Dnia 1 X 1697 r. poślubił Gertrudę Catharinę, wdowę po Krzysztofie Szymanowskim $^{138}$. Żona zmarła w marcu 1704 r. i została pochowana 1 kwietnia tego roku ${ }^{139}$. Już 4 XI 1704 r. Michael ożenił się powtórnie, z Constantią, córką mielcarza Heinricha Zieglera ${ }^{140}$. Z pierwszego lub drugiego małżeństwa Tiedeman miał córkę nieznanego imienia, która

\footnotetext{
${ }^{131}$ Ibid., k. 254v.

${ }^{132}$ Ibid., k. 256v.

${ }^{133}$ APT, Cech malarzy, sygn. 4, s. 220.

${ }^{134}$ AADDT, NMP, sygn. AA001, s. 375.

${ }^{135}$ MUTGA, nr 6844.

${ }^{136}$ APT, Cech malarzy, sygn. 4, s. 167, 168.

${ }^{137}$ G. Erler, Die Matrikel der Albertus-Universität zu Königsberg i Pr., Bd.2, Die Immatrikulationen von 1657-1829, Leipzig 1911-1912, s. 178.

${ }^{138}$ Evangelisches Zentralarchiv in Berlin (dalej cyt. EZA Berlin), sygn. 7642: Strasburg / Westpreußen, Kirchenbuch 1630-1732, s. 336. Swoje wypisy z ksiąg metrykalnych przechowywanych w Evangelisches Zentralarchiv in Berlin udostępniła dr Katarzyna

${ }_{140}^{139}$ EZA Berlin, sygn. 7642, s. 79.

${ }^{140}$ Ibid., s. 340 .
} Krupska. 
pochowana została w Brodnicy 17 VI 1706 r. ${ }^{141}$ Inna córka urodzona w Brodnicy zmarła już w Toruniu, jej pogrzeb odbył się 23 XI 1708 r. ${ }^{142}$

W 1707 r. Michael Tiedeman przeniósł się do rodzinnego Torunia, gdzie uzyskał stanowisko kancelisty. Początkowo mieszkał na Starym Mieście, być może w mieszkaniu przy siedzibie kancelarii miejskiej w kamienicy przy Rynku - naprzeciwko ratusza (Rynek Staromiejski 6 [A]). Już w 1710 r. został pisarzem urzędu opiekuńczego, w 1721 r. objął urząd ławnika przedmiejskiego, natomiast w 1723 r. awansował na ławnika nowomiejskiego ${ }^{143}$. W tym czasie przeniósł się do domu rodzinnego przy ul. Sukienniczej. W $1731 \mathrm{r}$. uzyskał stanowisko starszego Ławy Nowomiejskiej. Z nieznanych przyczyn (może w związku ze złą sytuacją materialną) w 1738 r. zrezygnował z piastowanego urzędu i powrócił do Brodnicy. Co ciekawe, w marcu tego roku odnotowany został $\mathrm{w}$ Toruniu jedynie $\mathrm{z}$ córką - być może żona już wcześniej wyjechała z miasta. Tiedeman mieszkał w Brodnicy aż do śmierci 2 XII 1747 r. ${ }^{144}$ Wdowa Constantia zmarła rok później, 4 grudnia $^{145}$.

W Toruniu przyszło na świat siedmioro dzieci Michaela i Constantii: Michael Gottlieb (chrz. 10 VII $1707^{146}$ ), Anna Concordia (chrz. 26 III $1713^{147}$ ), Florentina Dorothea (chrz. 12 IV $1714^{148}$ ), Benigna (chrz. 24 IX $1716^{149}$ ), Paul Benjamin (chrz. 24 I 1719 150 ), Maria Elisabeth (chrz. 26 XI $1720^{151}$ ) i Regina Renata (chrz. 18 II $1723^{152}$ ). Najstarszy z synów, Michael Gottlieb, 18 III 1715 r. został zapisany do Toruńskiego Gimnazjum $^{153}$; jego dalsze losy nie są znane. Florentina Dorothea 20 I 
1733 r. została wydana za mąż za kipera Johanna Georga Dietrichse$n^{154}$. Zapewne zmarła wkrótce po urodzeniu syna Johanna Georga (chrz. 1 I $1734^{155}$ ) - brakuje dalszych informacji na jej temat. W księgach pogłównego z lat 1734 i 1735 oraz 1738 odnotowano przy Tiedemanach po jednej córce, mającej ukończone co najmniej 10 lat: być może były to Maria Elisabeth i Regina Renata ${ }^{156}$. O pozostałych dzieciach Michaela nie wiadomo nic więcej.

Tabela 6. Świadkowie chrztów dzieci Michaela Tiedemana

\begin{tabular}{|c|c|c|c|c|}
\hline Imię dziecka & Data & Świadek & Zawód & Źródło \\
\hline 1 & 2 & 3 & 4 & 5 \\
\hline $\begin{array}{l}\text { Michael } \\
\text { Gottlieb }\end{array}$ & 10 VII 1707 & Andreas Teßmer & cejgmacher & $\begin{array}{c}\text { APT, EGWN, } \\
\text { sygn. } 78, \\
\text { s. } 57 \\
\end{array}$ \\
\hline $\begin{array}{l}\text { Michael } \\
\text { Gottlieb }\end{array}$ & 10 VII 1707 & Jacob Wolff & powroźnik & $\begin{array}{l}\text { APT, EGWN, } \\
\text { sygn. } 78, \\
\text { s. } 57\end{array}$ \\
\hline $\begin{array}{l}\text { Michael } \\
\text { Gottlieb }\end{array}$ & 10 VII 1707 & Anna Zimmerman & żona uczonego & $\begin{array}{c}\text { APT, EGWN, } \\
\text { sygn. } 78, \\
\text { s. } 57\end{array}$ \\
\hline $\begin{array}{l}\text { Michael } \\
\text { Gottlieb }\end{array}$ & 10 VII 1707 & Martha Ziegler & & $\begin{array}{l}\text { APT, EGWN, } \\
\text { sygn. } 78, \\
\text { s. } 57 \\
\end{array}$ \\
\hline $\begin{array}{c}\text { Anna } \\
\text { Concordia }\end{array}$ & 26 III 1713 & $\begin{array}{c}\text { Johann Gottfried } \\
\text { Rößner }\end{array}$ & uczony & $\begin{array}{l}\text { AADDT, NMP, } \\
\text { sygn. AA002, s. } \\
201\end{array}$ \\
\hline $\begin{array}{c}\text { Anna } \\
\text { Concordia }\end{array}$ & 26 III 1713 & Samuel Schönwald & pastor & $\begin{array}{c}\text { AADDT, NMP, } \\
\text { sygn. AA002, } \\
\text { s. } 201 \\
\end{array}$ \\
\hline $\begin{array}{c}\text { Anna } \\
\text { Concordia }\end{array}$ & 26 III 1713 & Catharina Bledorn & żona kuśnierza & $\begin{array}{c}\text { AADDT, NMP, } \\
\text { sygn. AA002, } \\
\text { s. } 201\end{array}$ \\
\hline $\begin{array}{c}\text { Anna } \\
\text { Concordia }\end{array}$ & 26 III 1713 & Anna Stern & żona kupca & $\begin{array}{c}\text { AADDT, NMP, } \\
\text { sygn. AA002, } \\
\text { s. } 201\end{array}$ \\
\hline $\begin{array}{c}\text { Anna } \\
\text { Concordia }\end{array}$ & 26 III 1713 & Anna Kelbel & żona kupca & $\begin{array}{l}\text { AADDT, NMP, } \\
\text { sygn. AA002, } \\
\text { s. } 201\end{array}$ \\
\hline
\end{tabular}

${ }^{154}$ APT, EGWN, sygn. 77, s. 231.

${ }^{155}$ Ibid., sygn. 78, s. 374.

${ }^{156}$ APT, Księgi pogłównego, t. 6, s. 132, 279; t. 7, s. 463. 


\begin{tabular}{|c|c|c|c|c|}
\hline 1 & 2 & 3 & 4 & 5 \\
\hline $\begin{array}{c}\text { Florentina } \\
\text { Dorothea }\end{array}$ & 12 IV 1714 & Wilhelm Łęcki & piwowar & $\begin{array}{l}\text { AADDT, NMP, } \\
\text { sygn. AA002, } \\
\text { s. } 210\end{array}$ \\
\hline $\begin{array}{c}\text { Florentina } \\
\text { Dorothea }\end{array}$ & 12 IV 1714 & Conrad Weinknecht & piwowar & $\begin{array}{c}\text { AADDT, NMP, } \\
\text { sygn. AA002, } \\
\text { s. } 210 \\
\end{array}$ \\
\hline $\begin{array}{c}\text { Florentina } \\
\text { Dorothea }\end{array}$ & 12 IV 1714 & Elisabeth Zöller & $\begin{array}{c}\text { wdowa } \\
\text { po piwowarze }\end{array}$ & $\begin{array}{l}\text { AADDT, NMP, } \\
\text { sygn. AA002, } \\
\text { s. } 210\end{array}$ \\
\hline $\begin{array}{c}\text { Florentina } \\
\text { Dorothea }\end{array}$ & 12 IV 1714 & Constantia Teßmer & żona cejgmachera & $\begin{array}{c}\text { AADDT, NMP, } \\
\text { sygn. AA002, } \\
\text { s. } 210 \\
\end{array}$ \\
\hline $\begin{array}{c}\text { Florentina } \\
\text { Dorothea }\end{array}$ & 12 IV 1714 & Dorothea Leuschner & żona kotlarza & $\begin{array}{c}\text { AADDT, NMP, } \\
\text { sygn. AA002, } \\
\text { s. } 210 \\
\end{array}$ \\
\hline Benigna & 24 IX 1716 & Michael Thiel & piekarz & $\begin{array}{c}\text { AADDT, NMP, } \\
\text { sygn. AA002, } \\
\text { s. } 226 \\
\end{array}$ \\
\hline Benigna & 24 IX 1716 & Elisabeth Will & żona zegarmistrza & $\begin{array}{c}\text { AADDT, NMP, } \\
\text { sygn. AA002, } \\
\text { s. } 226 \\
\end{array}$ \\
\hline Benigna & 24 IX 1716 & Regina Jantzen & żona kupca & $\begin{array}{l}\text { AADDT, NMP, } \\
\text { sygn. AA002, } \\
\text { s. } 226\end{array}$ \\
\hline $\begin{array}{c}\text { Paul } \\
\text { Benjamin }\end{array}$ & 24 I 1719 & Heinrich Blavier & cejgmacher & $\begin{array}{c}\text { AADDT, NMP, } \\
\text { sygn. AA002, } \\
\text { s. } 241\end{array}$ \\
\hline $\begin{array}{l}\text { Paul Benja- } \\
\text { min }\end{array}$ & 24 I 1719 & Jacob Merckner & piwowar & $\begin{array}{l}\text { AADDT, NMP, } \\
\text { sygn. AA002, } \\
\text { s. } 241\end{array}$ \\
\hline $\begin{array}{c}\text { Paul } \\
\text { Benjamin }\end{array}$ & 24 I 1719 & Elisabeth Schultz & córka kupca & $\begin{array}{c}\text { AADDT, NMP, } \\
\text { sygn. AA002, } \\
\text { s. } 241\end{array}$ \\
\hline $\begin{array}{l}\text { Maria } \\
\text { Elisabeth }\end{array}$ & 26 XI 1720 & Erdman Jantzen & kupiec & $\begin{array}{c}\text { AADDT, NMP, } \\
\text { sygn. AA002, } \\
\text { s. } 255 \\
\end{array}$ \\
\hline $\begin{array}{c}\text { Maria } \\
\text { Elisabeth }\end{array}$ & 26 XI 1720 & Abraham Will & zegarmistrz & $\begin{array}{l}\text { AADDT, NMP, } \\
\text { sygn. AA002, } \\
\text { s. } 255\end{array}$ \\
\hline $\begin{array}{c}\text { Maria } \\
\text { Elisabeth }\end{array}$ & 26 XI 1720 & Elisabeth Täuber & wdowa po kupcu & $\begin{array}{l}\text { AADDT, NMP, } \\
\text { sygn. AA002, } \\
\text { s. } 255 \\
\end{array}$ \\
\hline $\begin{array}{c}\text { Maria } \\
\text { Elisabeth }\end{array}$ & 26 XI 1720 & Catharina Döring & wdowa po kupcu & $\begin{array}{l}\text { AADDT, NMP, } \\
\text { sygn. AA002, } \\
\text { s. } 255\end{array}$ \\
\hline
\end{tabular}




\begin{tabular}{|c|c|c|c|c|}
\hline 1 & 2 & 3 & 4 & 5 \\
\hline $\begin{array}{c}\text { Maria } \\
\text { Elisabeth }\end{array}$ & 26 XI 1720 & Elisabeth Andres & żona piwowara & $\begin{array}{c}\text { AADDT, NMP, } \\
\text { sygn. AA002, } \\
\text { s. 255 }\end{array}$ \\
\hline $\begin{array}{c}\text { Regina } \\
\text { Renata }\end{array}$ & 18 II 1723 & Jacob Starck & piwowar & $\begin{array}{c}\text { APT, EGWN, } \\
\text { sygn. 78, } \\
\text { s. 239 }\end{array}$ \\
\hline $\begin{array}{c}\text { Regina } \\
\text { Renata }\end{array}$ & 18 II 1723 & Elisabeth Ratzki & żona kupca & $\begin{array}{c}\text { APT, EGWN, } \\
\text { sygn. 78, } \\
\text { s. 239 }\end{array}$ \\
\hline $\begin{array}{l}\text { Regina } \\
\text { Renata }\end{array}$ & 18 II 1723 & $\begin{array}{c}\text { Elisabeth } \\
\text { Weinknecht }\end{array}$ & żona piwowara & $\begin{array}{c}\text { APT, EGWN, } \\
\text { sygn. 78, } \\
\text { s. 239 }\end{array}$ \\
\hline
\end{tabular}

Świadkami przy chrztach dzieci Michaela byli przedstawiciele najwyższych warstw społecznych w Toruniu: 16 członków władz miejskich i ich żony, pastor, pięć kobiet z rodzin kupieckich, pięciu reprezentantów bogatego rzemiosła oraz krewna żony z Brodnicy.

Tabela 7a. Chrzty, przy których świadkiem był Michael Tiedeman

\begin{tabular}{|c|c|c|c|c|c|c|c|}
\hline Data & \begin{tabular}{|c|} 
Nazwisko \\
dziecka
\end{tabular} & $\begin{array}{c}\text { Imię } \\
\text { dziecka }\end{array}$ & Imię ojca & $\begin{array}{c}\text { Zawód } \\
\text { ojca }\end{array}$ & $\begin{array}{c}\text { Nazwisko } \\
\text { matki }\end{array}$ & Imię matki & Źródło \\
\hline 1 & 2 & 3 & 4 & 5 & 6 & 7 & 8 \\
\hline $\begin{array}{c}16 \\
\text { III } \\
1706\end{array}$ & Stahn & $\begin{array}{l}\text { Anna } \\
\text { Maria }\end{array}$ & Christian & postrzygacz & Tiedeman & Maria & $\begin{array}{c}\text { APT, } \\
\text { EGWNM, } \\
\text { sygn. } 78, \\
\text { s. } 47\end{array}$ \\
\hline $\begin{array}{c}29 \\
\text { IV } \\
1708\end{array}$ & Barck & Daniel & Simon & snycerz & Tiedeman & Elisabeth & $\begin{array}{c}\text { AADDT, } \\
\text { NMP, } \\
\text { sygn. AA002, } \\
\text { s. } 166\end{array}$ \\
\hline $\begin{array}{c}4 \\
\text { II } \\
1714\end{array}$ & Leuschner & $\begin{array}{l}\text { Johann } \\
\text { Gottlieb }\end{array}$ & Christian & kotlarz & Schäffer & Dorothea & $\begin{array}{c}\text { APT, } \\
\text { EGWNM, } \\
\text { sygn. } 78, \\
\text { s. } 120\end{array}$ \\
\hline $\begin{array}{c}29 \\
\text { IX } \\
1714\end{array}$ & Stahn & Michael & Christian & postrzygacz & Tiedeman & Maria & $\begin{array}{c}\text { APT, } \\
\text { EGWNM, } \\
\text { sygn. } 78, \\
\text { s. } 126 \\
\end{array}$ \\
\hline $\begin{array}{c}22 \\
\text { IX } \\
1715\end{array}$ & Tracz & Stanisław & Stanisław & tracz & $\mathrm{N}$ & Elżbieta & \begin{tabular}{|c} 
AADDT, \\
Jakub, \\
sygn. AA001, \\
s. 307 \\
\end{tabular} \\
\hline
\end{tabular}




\begin{tabular}{|c|c|c|c|c|c|c|c|}
\hline 1 & 2 & 3 & 4 & 5 & 6 & 7 & 8 \\
\hline $\begin{array}{c}12 \\
\text { VII } \\
1716 \\
\end{array}$ & Behnisch & Gottfried & Gottfried & powroźnik & Conrad & Elisabeth & $\begin{array}{c}\text { APT, } \\
\text { EGWN, } \\
\text { sygn. } 78, \\
\text { s. } 144\end{array}$ \\
\hline $\begin{array}{c}27 \\
\text { IX } \\
1716 \\
\end{array}$ & Bernhard & $\begin{array}{l}\text { Christina } \\
\text { Charlotta }\end{array}$ & $\begin{array}{c}\text { Georg } \\
\text { Christian }\end{array}$ & żołnierz & Brißge & Euphrosina & $\begin{array}{l}\text { AADDT, } \\
\text { NMP, } \\
\text { sygn. AA002, } \\
\text { s. } 226 \\
\end{array}$ \\
\hline $\begin{array}{c}8 \\
\text { XII } \\
1716 \\
\end{array}$ & Zieger & $\begin{array}{c}\text { Benjamin } \\
\text { Gottlieb }\end{array}$ & Gottfried & kotlarz & Leuschner & Judith & $\begin{array}{c}\text { APT, } \\
\text { EGWNM, } \\
\text { sygn. } 78, \\
\text { s. } 150\end{array}$ \\
\hline $\begin{array}{c}24 \\
\text { IX } \\
1717 \\
\end{array}$ & Gryziewicz & Michael & Michał & garncarz & Baptzin & $\begin{array}{c}\text { Christina } \\
\text { Euphrosina }\end{array}$ & \begin{tabular}{|c} 
AADDT, \\
Jakub, \\
sygn. AA001, \\
s. 325 \\
\end{tabular} \\
\hline $\begin{array}{c}17 \\
\text { III } \\
1718\end{array}$ & Kowalski & Józef & Jakub & plebs & Chwałcik & Katarzyna & $\begin{array}{c}\text { AADDT, } \\
\text { Jakub, } \\
\text { sygn. AA001, } \\
\text { s. } 331\end{array}$ \\
\hline $\begin{array}{c}7 \\
\text { VIII } \\
1718 \\
\end{array}$ & Will & $\begin{array}{l}\text { Johann } \\
\text { Samuel }\end{array}$ & Abraham & $\begin{array}{l}\text { zegar- } \\
\text { mistrz }\end{array}$ & Schäffer & Elisabeth & \begin{tabular}{|c|} 
AADDT, \\
NMP, \\
sygn. AA002, \\
s. 239 \\
\end{tabular} \\
\hline $\begin{array}{c}12 \\
\text { VII } \\
1719\end{array}$ & Thiel & $\begin{array}{c}\text { Johann } \\
\text { Jacob }\end{array}$ & Abraham & piekarz & Schultz & Anna & $\begin{array}{c}\text { AADDT, } \\
\text { NMP, } \\
\text { sygn. AA002, } \\
\text { s. } 246 \\
\end{array}$ \\
\hline $\begin{array}{c}2 \\
\text { II } \\
1720 \\
\end{array}$ & Mülich & Catharina & Alexander & balwierz & Müller & Catharina & \begin{tabular}{|c} 
AADDT, \\
NMP, \\
sygn. AA002, \\
s. 249 \\
\end{tabular} \\
\hline $\begin{array}{c}1 \\
\text { I } \\
1734 \\
\end{array}$ & Dietrichsen & $\begin{array}{l}\text { Johann } \\
\text { Georg }\end{array}$ & $\begin{array}{l}\text { Johann } \\
\text { Georg }\end{array}$ & kiper & Tiedeman & $\begin{array}{c}\text { Florentina } \\
\text { Dorothea }\end{array}$ & \begin{tabular}{|c} 
APT, \\
EGWNM, \\
sygn. 78, \\
s. 374 \\
\end{tabular} \\
\hline
\end{tabular}

Tabela 7b. Chrzty, przy których świadkiem była Constantia Tiedeman

\begin{tabular}{|c|c|c|c|c|c|c|c|}
\hline Data & $\begin{array}{c}\text { Nazwisko } \\
\text { dziecka }\end{array}$ & $\begin{array}{c}\text { Imię } \\
\text { dziecka }\end{array}$ & Imię ojca & $\begin{array}{c}\text { Zawód } \\
\text { ojca }\end{array}$ & $\begin{array}{c}\text { Nazwisko } \\
\text { matki }\end{array}$ & Imię matki & Źródło \\
\hline 1 & 2 & 3 & 4 & 5 & 6 & 7 & 8 \\
\hline 29 & Stahn & Gottfried & Christian & postrzygacz & Tiedeman & Maria & $\begin{array}{c}\text { APW, } \\
\text { EGWM, } \\
\text { sygn. 78, } \\
\text { s. 78 }\end{array}$ \\
$\begin{array}{c}\text { VIII } \\
1709\end{array}$ & S \\
\hline
\end{tabular}




\begin{tabular}{|c|c|c|c|c|c|c|c|}
\hline 1 & 2 & 3 & 4 & 5 & 6 & 7 & 8 \\
\hline $\begin{array}{c}21 \\
\text { VIII } \\
1711\end{array}$ & Rohn & Michael & Antonius & murarz & Neuman & Maria & \begin{tabular}{|c|} 
AADDT, \\
NMP, \\
sygn. AA002, \\
s. 188
\end{tabular} \\
\hline $\begin{array}{c}7 \\
\mathrm{I} \\
1712\end{array}$ & Gärtner & $\begin{array}{l}\text { Johann } \\
\text { Christian }\end{array}$ & $\begin{array}{c}\text { Georg } \\
\text { Christian }\end{array}$ & kominiarz & Mohrholt & Anna & \begin{tabular}{|} 
AADDT, \\
NMP, \\
sygn. AA002, \\
s. 192
\end{tabular} \\
\hline $\begin{array}{c}9 \\
\text { VII } \\
1713\end{array}$ & Brandt & Jacob & Jacob & wieś & Vandrei & Anna & \begin{tabular}{|c|} 
AADDT, \\
NMP, \\
sygn. AA002, \\
s. 203
\end{tabular} \\
\hline $\begin{array}{c}27 \\
X \\
1715\end{array}$ & Mede & Andreas & Peter & wieś & Vandrei & Catharina & \begin{tabular}{|c|} 
AADDT, \\
NMP, \\
sygn. AA002, \\
s. 219
\end{tabular} \\
\hline $\begin{array}{c}8 \\
\text { III } \\
1720\end{array}$ & Abend & Gottfried & Andreas & sukiennik & Arlet & Christina & $\begin{array}{c}\text { APT, } \\
\text { EGWNM, } \\
\text { sygn. } 78, \\
\text { s. } 196\end{array}$ \\
\hline
\end{tabular}

Tiedeman był z kolei świadkiem przy 14 chrztach. Ze względu na zajmowaną pozycję społeczną status jego chrześniaczek i chrześniaków był wyższy niż w przypadku jego braci. Dwukrotnie świadkował przy chrztach dzieci siostry Marii, raz - swojego wnuka, osiem razy noworodków z warstwy rzemieślniczej oraz trzy razy dzieci nieobywateli (w tym dwóch katolików). Jego żona trzymała do chrztu sześcioro dzieci - siostrzeńca męża, trójkę potomstwa z rodzin rzemieślniczych i dwoje dzieci gospodarzy z okolicznych wsi. Warto zaznaczyć, że poza jednym chrztem (wnuka) wszystkie pozostałe miały miejsce przed 1721 r., a więc przed uzyskaniem stanowiska w ławie nowomiejskiej i przenosinami na Nowe Miasto.

Ze względu na zajmowane stanowisko Michael płacił stosunkowo dużą stawkę pogłównego. O jego niezbyt wysokim statusie majątkowym świadczyć może jednak fakt, że jedynie w latach 1723-1725 zatrudniał służącą ${ }^{157}$.

\footnotetext{
${ }^{157}$ Ibid., t. 1 , s. $284,465,665$; t. 3 , s. 76.
} 
Zaprezentowana powyżej, nieznana dotąd dekoracja stropu w kamienicy przy ulicy Żeglarskiej 16 jest wyjątkowa na tle innych toruńskich realizacji tego typu. Wyróżnia się bogatym programem ikonograficznym świadczącym o szerokich horyzontach intelektualnych właściciela - Jacoba Heinricha Zerneckego. Centralna scena, alegoria Prawda córka Czasu, oparta została na kompozycji Nicolasa Poussina. Jest to największe znane przedstawienie figuralne umieszczone na stropie toruńskiej kamienicy. Na podkreślenie zasługuje także fakt zastosowania kompozycji iluzjonistycznej, zacierającej różnicę między malarstwem i rzeczywistą architekturą. Analiza źródeł archiwalnych pozwoliła wysunąć tezę o powierzeniu prac dekoracyjnych miejscowemu mistrzowi Johannowi Tiedemanowi młodszemu oraz wyznaczyć czas powstania dzieła na okres krótko po powrocie świeżo zaślubionych Jacoba Heinricha i Concordii Zernecke do Torunia w czerwcu 1702 r.

Losy rodziny Tiedemanów stanowią ciekawy przykład społecznego awansu w nowożytnym mieście. Protoplasta rodziny, Johann (I), przybył około $1631 \mathrm{r}$. do Torunia jako czeladnik, zapewne $\mathrm{z}$ zamiarem uzyskania stopnia mistrza $\mathrm{w}$ cechu stolarskim oraz wejścia do grupy obywateli. Nie udało mu się tego osiągnąć, więc karierę związał ze służbą miejską jako żołnierz. Dwóch swoich synów zdołał zapisać na naukę w Toruńskim Gimnazjum, a jeden z nich, Johann (II), przeszed 1 następnie pełną edukację w warsztacie malarskim, zwieńczoną otrzymaniem patentu mistrzowskiego oraz praw miejskich. Stopniowo jego pozycja rosła, co uwidacznia dobór świadków na chrztach jego potomstwa, wywodzących się z coraz wyższych grup społecznych. Wszyscy trzej synowie Johanna (II), którzy przeżyli wczesne dzieciństwo, odbyli zarówno naukę w gimnazjum, jak i termin w jego warsztacie. Johann (III) młodszy oraz Daniel w przyszłości zostali malarzami, natomiast Michael zrobił karierę urzędniczą, przypieczętowaną funkcją starszego Ławy Nowomiejskiej. Co ciekawe, wszyscy trzej bracia opuścili Toruń, zapewne w wyniku kłopotów finansowych. Wyjazd Michaela do Brodnicy w 1738 r. zakończył trzypokoleniowe i ponad stuletnie związki Tiedemanów z Toruniem. 
Streszczenie: Podczas prac remontowych w kamienicy przy ul. Żeglarskiej 16 w Toruniu odkryto dekorację w formie malarstwa iluzjonistycznego, umieszczoną na drewnianym stropie sieni. Centralna scena przedstawia alegorię Prawda córka Czasu: Chronosa unoszącego w niebiosa nagą kobietę - personifikację Prawdy, ratującego ją od wpływów Niezgody i Zawiści ukazanych jako kobiety siedzące na skraju sceny. Malowidło jest powtórzeniem kompozycji Nicolasa Poussina, wykonanej w 1641 r. na zlecenie kardynała Richelieu i przeznaczonej na sufit jego prywatnego apartamentu w pałacu kardynalskim w Paryżu. Dzieło to rozpowszechnione było w Europie za sprawą kilku wersji rycin, z których najbliższa toruńskiej wersji jest ta autorstwa Bernarda Picarda. Dekoracje stropu uzupełniają putta z koszami owocowymi, anioły oraz cztery portrety stylizowane na rzeźbione popiersia. Przedstawiają one właściciela kamienicy Jacoba Heinricha Zernecke, jego żonę Concordię oraz jego rodziców: Johanna i Christinę.

Na podstawie analizy źródeł archiwalnych można wysunąć tezę o powierzeniu prac dekoracyjnych miejscowemu mistrzowi Johannowi Tiedemanowi młodszemu, którego syn Georg trzymany był do chrztu przez Johanna i Concordię Zernecke 13 sierpnia 1702 r. Czas powstania malowidła wyznaczyć należy na okres krótko po powrocie świeżo zaślubionych Jacoba Heinricha i Concordii Zernecke do Torunia w czerwcu 1702 r.

$\mathrm{Z}$ rodziny Tiedemanów, związanej z Toruniem od $1631 \mathrm{r}$., wywodziło się trzech malarzy, członków toruńskiego cechu: Johann starszy (1633-1705) oraz jego synowie Johann młodszy (1669 - po 1718) i Daniel (1674 - po 1722). Dodatkowo Michael (1671-1747), trzeci z synów Johanna starszego, zrobił karierę urzędniczą przypieczętowaną funkcją starszego Ławy Nowomiejskiej w Toruniu.

\section{Decoration of the ceiling in the burgher house of Jacob Heinrich Zernecke at 16 Żeglarska Street and the history of the Tiedemans, a family of Torun painters}

Abstract: During the renovation works in the burgher house at 16 Żeglarska Street in Torun a trompe-l'œil decoration was discovered on the wooden ceiling of the foyer. The central scene depicts the allegory Veritas temporis filia est: Chronos holding a naked woman - a personification of Truth - and raising her to the sky thusly saving her from the influence of Discord and Envy portrayed as women sitting on the ground. The scene replicates the composition of a painting by Nicolas Poussin made in 1641 upon the commission of Cardinal 
Richelieu, which was intended to be placed on the ceiling of a private apartment in the cardinal's palace in Paris. The composition was popularized in entire Europe thanks to circulating graphic versions - the painting in Torun mostly resembles an engraving made by Bernard Picard. The decoration of the ceiling is complemented with depictions of putti carrying baskets full of fruit, angels and four portraits imitating sculpted busts. They represent the owner of the burgher house Jacob Heinrich Zernecke, his wife Concordia and his parents: Johann and Christina.

On the basis of archival sources a thesis can be proposed that the decorations were made by the local painter Johann Tiedeman the Younger. On 13 August 1702 Johann and Concordia Zernecke became the godparents of his son Georg. Hence the commission of the ceiling painting most likely occurred shortly after the return of the newly married Jacob Heinrich and Concordia Zernecke to Toruń in June 1702.

The Tiedeman family was associated with Torun since 1631 . Three of its members became masters in the local painters guild: Johann the Elder (16331705) and his sons Johann the Younger (1669 - after 1718) and Daniel (1674after 1722). Moreover, Michael (1671-1747), the third son of Johann the Elder, made a career as a clerk - he eventually became a scabinus (Schöffe) of the New City of Torun.

Barttomiej Łyczak

\section{Die Deckenverzierung im Haus von Jacob Heinrich Zernecke in der Segler (Żeglarska) Straße 16 und die Geschichte der Thorner Malerfamilie Tiedeman}

Zusammenfassung: Bei Renovierungsarbeiten im Haus in der Segler (Żeglarska) Straße 16 in Thorn wurde eine Dekoration in Form einer illusionistischen Malerei gefunden, die an der Holzdecke im Flur angebracht ist. Die zentrale Szene zeigt eine Allegorie Die Wahrheit als Tochter der Zeit, auf der Chronos eine nackte Frau, die Personifikation der Wahrheit, in den Himmel trägt und sie vor den Einflüssen der Zwietracht und des Neides rettet, die als zwei Frauen gezeigt werden, die am Rand der Szene sitzen. Die Malerei ist die Wiederholung einer Komposition von Nicolas Poussin, die er im Jahr 1641 im Auftrag von Kardinal Richelieu ausführte und die für die Decke des privaten Appartements in dessen Kardinalspalast in Paris bestimmt war. Dieses Werk wurde in Europa durch mehrere Versionen von Abbildungen verbreitet, von 
denen die von Bernard Picard der Thorner Version am nächsten steht. Die Verzierung der Decke wird vervollständigt durch Putten mit Obstkörben, Engel sowie vier Porträts, die als skulptierte Büsten stilisiert sind. Sie stellen den Eigentümer des Hauses, Jacob Heinrich Zernecke, seine Frau Concordia und seine Eltern Johann und Christine dar.

Die Analyse archivalischer Quellen lässt den Schluss zu, dass mit den Dekorationsarbeiten der örtliche Meister Johann Tiedeman der Jüngere beauftragt war, dessen Sohn Georg bei seiner Taufe am 13. August 1702 Johanna und Concordia Zernecke als Taufpaten hatte. Die Entstehungszeit der Malerei lässt sich auf die Zeit kurz nach der Rückkehr der frisch verheirateten Jacob Heinrich und Concordia Zernecke nach Thorn im Juni 1702 datieren.

Aus der Familie Tiedeman, die seit 1631 mit Thorn verbunden war, stammten drei Maler, die Mitglied der Thorner Zunft waren: Johann der Ältere (1633-1705) sowie seine Söhne Johann der Jünger (1669 - nach 1718) und Daniel (1674 - nach 1722). Darüber hinaus machte Michael (1671-1747), der dritte Sohn von Johann dem Älteren, eine Beamtenkarriere, die er mit der Funktion des Schöppenmeisters der Neustadt Thorn krönte.

Słowa kluczowe: cechy rzemieślnicze, demografia, malarstwo, Toruń, sztuka baroku

Keywords: craft guild, demography, painting, Toruń, Baroque art

Schlüsselwörter: Handwerkerzünfte, Demografie, Malerei, Thorn, Barockkunst 